\title{
Concurrent observations of air pollutants at two sites in the Pearl River Delta and the implication of regional transport
}

\author{
H. Guo ${ }^{1}$, F. Jiang ${ }^{1,2}$, H. R.Cheng ${ }^{1}$, I. J. Simpson ${ }^{3}$, X. M. Wang ${ }^{4}$, A. J. Ding ${ }^{1,2}$, T. J. Wang ${ }^{2}$, S. M. Saunders ${ }^{5}$, T. Wang ${ }^{1}$, \\ S. H. M. Lam ${ }^{5}$, D. R. Blake ${ }^{3}$, Y. L. Zhang ${ }^{1,4}$, and M. Xie ${ }^{1,2}$ \\ ${ }^{1}$ Air Quality Studies, Department of Civil and Structural Engineering, the Hong Kong Polytechnic University, Hong Kong \\ ${ }^{2}$ School of Atmospheric Sciences, Nanjing University, Nanjing, China \\ ${ }^{3}$ Department of Chemistry, University of California at Irvine, California, USA \\ ${ }^{4}$ Guangzhou Institute of Geochemistry, Chinese Academy of Sciences, Guangzhou, China \\ ${ }^{5}$ School of Biomedical, Biomolecular and Chemical Sciences, University of Western Australia, Perth, Australia
}

Received: 12 March 2009 - Published in Atmos. Chem. Phys. Discuss.: 16 April 2009

Revised: 5 August 2009 - Accepted: 18 September 2009 - Published: 2 October 2009

\begin{abstract}
An intensive field measurement study was conducted simultaneously at a site within the inland Pearl River Delta (PRD) region (WQS) and a site in Hong Kong (TC) between 22 October and 1 December 2007. Ambient air pollutants measured included $\mathrm{O}_{3}, \mathrm{NO}_{\mathrm{x}}, \mathrm{CO}, \mathrm{SO}_{2}, \mathrm{NMHCs}$, and carbonyls. The purpose is to improve our understanding of the interplay among local and regional air pollutants in the Hong Kong area, and the influence of regional transport on local air pollutants. The results indicate that the mean levels of air pollutants at the WQS site were much higher than those at the TC site, except $\mathrm{NO}_{\mathrm{x}}$. Thirteen $\mathrm{O}_{3}$ episode days (daily $\mathrm{O}_{3}$ peak in excess of $122 \mathrm{ppbv}$ ) were monitored at WQS during the study period, while only 2 days were recorded at TC. Diurnal variations of $\mathrm{O}_{3}$ showed higher nighttime levels of $\mathrm{O}_{3}$ at TC than at WQS as well as more photochemical activity at WQS than TC. Remarkable differences in diurnal variations were also found between high and low $\mathrm{O}_{3}$ pollution days at each site, implying that Hong Kong is more acutely VOC-limited than the inland PRD region. Ratio analyses for trace gases and VOCs and back trajectory calculation revealed that the air masses arriving at WQS were more aged due to regional influence, whereas the air masses at TC were mainly affected by local emissions and/or regional transport. In addition, the influence of regional transport from Eastern China on the primary pollutants of Hong Kong was noticeable, whereas the air masses from the inland PRD region (e.g. Dongguan and Huizhou) had significant influence on the air pollutants at WQS, and the anthropogenic emissions
\end{abstract}

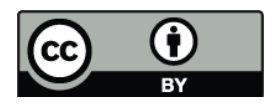

Correspondence to: $\mathrm{H}$. Guo

(ceguohai@polyu.edu.hk) in Eastern PRD (e.g. Shenzhen) played an important role on the photochemical ozone pollution in Western Hong Kong. These results confirm that regional and sub-regional transport of air pollution has a complex and significant impact on local air pollutants in this region.

\section{Introduction}

One of the major problems facing the environmental society is photochemical smog. Photochemical smog is the result of the interaction of sunlight with certain chemicals in the atmosphere, which leads to ground-level ozone $\left(\mathrm{O}_{3}\right)$ and airborne particles (NRC, 1991; Seinfeld and Pandis, 2006). Photochemical smog is a concern in most major urban centers but, because it travels with the wind, it can affect sparsely populated areas as well. Smog can be formed in almost any climate where industries or cities release large amounts of air pollution. However, it is worse during periods of warmer, sunnier weather when the upper air is warm enough to dampen or inhibit vertical circulation. Photochemical smog is especially prevalent in geologic basins encircled by hills or mountains. It often stays for an extended period of time over densely populated cities, such as Hong Kong, and can build up to dangerous levels. The photochemically formed $\mathrm{O}_{3}$ at ground level can have adverse effects on human health and also affects the oxidizing capacity of the atmosphere, while the secondary organic aerosols formed have direct effects on climate change through modification of radiative budgets (Warneck, 2000; Godish, 2004). Globally, the carbon load is strongly influenced by anthropogenic activity,

Published by Copernicus Publications on behalf of the European Geosciences Union. 


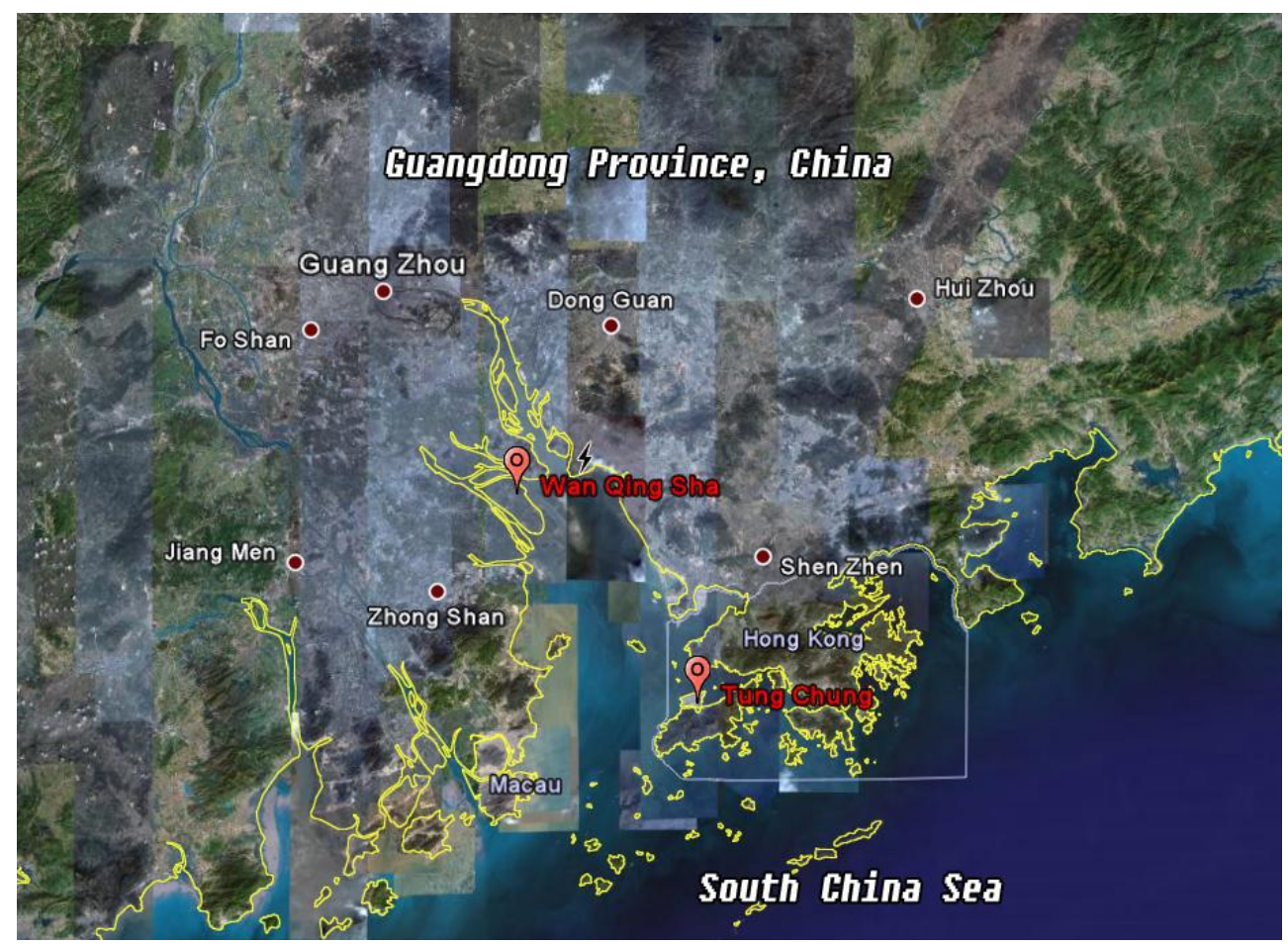

Fig. 1. Location of the sampling sites, Pearl River Delta of Southern China.

and future changes in emissions will continue to be a central consideration in air quality policy and climate change.

In recent years, the Pearl River Delta (PRD) region on the coast of Southern China has become one of the world's fastest growing industrial areas. The PRD region consists of nine cities within Guangdong Province, namely Guangzhou, Shenzhen, Zhuhai, Dongguan, Zhongshan, Foshan, Jiangmen, Huizhou and Zhaoqing (usually these nine cities are considered to comprise the inland PRD region), plus Hong Kong and Macau Special Administrative Regions (Fig. 1). A consequence of the rapid development is the sacrifice of environmental quality. Photochemical $\mathrm{O}_{3}$ has been studied in Southern China for over a decade. Lam et al. (1998) analyzed the behavior of background surface $\mathrm{O}_{3}$ measured at a coastal site in Hong Kong. Chan et al. (1998a, b) compared background and urban $\mathrm{O}_{3}$ in Hong Kong. They focused on seasonal variations of $\mathrm{O}_{3}$ and related the observed trends to the large-scale Asian monsoon circulation. Low $\mathrm{O}_{3}$ during summer was attributed to the inflow of maritime air, whereas abundant $\mathrm{O}_{3}$ in autumn-winter was due to the outflow of polluted continental air. Wang et al. (1998) found that the local-scale re-circulation was an important mechanism in transporting $\mathrm{O}_{3}$ to a rural/coastal monitoring site (Hok Tsui) near Hong Kong. The temporal variability and emission patterns related to photochemical smog episodes in Hong Kong were also reported by Wang et al. (2003) and Wang and Kwok (2003). So and Wang (2003) studied the ground-level $\mathrm{O}_{3}$ concentrations at four sites in Hong Kong.
In addition, many $\mathrm{O}_{3}$ episodes were analyzed in combination with the meteorological conditions in Hong Kong using numerical simulations (e.g. Lee et al., 2002; Wang and Kwok, 2003; Ding et al., 2004; Lam et al., 2005; Wang et al., 2006; Huang et al., 2006). These studies suggested the importance of regional transport from the inland PRD region. Lee and Savtchenko (2006) found that air pollution in Hong Kong was correlated with that in the inland PRD region in 2003 and 2004. Huang et al. (2006) surveyed $54 \mathrm{O}_{3}$ episodes that occurred over Hong Kong during 2000-2004 and found that $\mathrm{O}_{3}$ episodes were dominated by regional transport when a tropical cyclone/typhoon was located over the Northwestern Pacific or the South China Sea to the east or southeast and when an anticyclone appeared over mainland China to the north. Sensitivity studies even revealed that, in some $\mathrm{O}_{3}$ episodes, $40-90 \%$ of the ambient $\mathrm{O}_{3}$ at urban and rural areas of Hong Kong was attributed to horizontal transport (Lam et al., 2005; Wang et al., 2006). However, all of these studies were carried out within Hong Kong. The relative contributions of local photochemical formation and regional transport to $\mathrm{O}_{3}$ episodes in Hong Kong are not fully understood. Furthermore, the causes of $\mathrm{O}_{3}$ episodes in the inland PRD, which was considered as a major reason for $\mathrm{O}_{3}$ episodes in Hong Kong, remain unclear, though some studies have been undertaken inside the inland PRD region (e.g. Zhang, 1999, 2008). Therefore, in order to improve our understanding of the correlation between air pollution in Hong Kong and the inland PRD region, simultaneous measurements of $\mathrm{O}_{3}$ and 
its precursors (i.e. volatile organic compounds and nitrogen oxides) were conducted at both sites in October-December, 2007 (autumn is the period that $\mathrm{O}_{3}$ episodes are often observed).

Volatile organic compounds (VOCs) and nitrogen oxides $\left(\mathrm{NO}_{\mathrm{x}}\right)$ are important precursors of tropospheric $\mathrm{O}_{3}$. Studies have shown that the formation of $\mathrm{O}_{3}$ in the PRD region is limited by VOCs (So and Wang, 2004; Zhang et al., 2007; Zhang et al., 2008). A number of studies have been conducted to understand the spatial and temporal characteristics of VOCs in the inland PRD region (e.g. Chan et al., 2006; Tang et al., 2007; Barletta et al., 2008; Liu et al. 2008) and in the Hong Kong area (e.g. Sin et al., 2000; Lee et al., 2002; Guo et al., 2004, 2007; So and Wang, 2004; Zhang et al., 2007). The regional and local source contributions to ambient VOCs in Hong Kong have been studied by measurements at a rural/coastal site near Hong Kong (Wang, T. et al., 2005; Guo et al., 2006). These previous studies mainly focused on the speciation, spatial and temporal variations, source characterization and identification of VOCs either in Hong Kong or in the inland PRD. To better understand the relationship of VOCs between inland PRD and Hong Kong during $\mathrm{O}_{3}$ episodes, and the photochemistry of VOCs in the formation of $\mathrm{O}_{3}$, it is necessary to undertake concurrent field measurements in these two different areas.

In this study, we present the measurement data of the main air pollutants simultaneously collected between 22 October and 1 December 2007 at two sampling sites which are located in the inland PRD region and in Hong Kong, respectively. The levels of individual trace gases, total non-methane hydrocarbons (NMHCs), and total carbonyls in both areas are reported here, and the differences and relationships of the air pollutant concentrations at the two sites are discussed. Temporal patterns of total NMHCs and other trace gases are compared between high and low $\mathrm{O}_{3}$ pollution days. In particular, high $\mathrm{O}_{3}$ episodes are analyzed in combination with the meteorological conditions. Finally, we discuss the influence of regional transport on these study areas by examining the relationship between selected VOC species ratios and the age of air masses, and by analyzing their backward trajectories.

\section{Methodology}

\subsection{Description of the sampling sites}

The field measurement sampling sites - Wan Qing Sha (WQS) and Tung Chung (TC) - are shown in Fig. 1. The distance between the two sites is about $62 \mathrm{~km}$. WQS $\left(22.711^{\circ} \mathrm{N}, 113.549^{\circ} \mathrm{E}\right)$ is a small town located near the center of the PRD. This small town is surrounded by farmlands and has very few textile and clothing workshops, so the local anthropogenic emissions are not remarkable. The major air pollutants are mainly from the surrounding cities. This site is $50 \mathrm{~km}$ to the southeast of the Guangzhou urban center, $40 \mathrm{~km}$ southwest of Dongguan, $50 \mathrm{~km}$ northwest of Shenzhen, and $25 \mathrm{~km}$ northeast of Zhongshan, making it a good location to characterize the air pollution in the inland PRD. Conversely, since WQS is at the northernmost boundary of the Pearl Estuary and to the northwest of Hong Kong, it is an appropriate site to investigate the influence of the inland PRD region on Hong Kong when northerly wind is prevalent. The measurements were carried out on the rooftop of a $15 \mathrm{~m}$ high building.

TC $\left(22.30^{\circ} \mathrm{N}, 113.93^{\circ} \mathrm{E}\right)$ is located on northern Lantau Island, about $3 \mathrm{~km}$ south of the Hong Kong International airport at Chek Lap Kok. It is a newly-developed residential town, but adjacent to the highway and to railway lines. It is about $20 \mathrm{~km}$ to the southwest of Hong Kong urban center, and $38 \mathrm{~km}$ northeast of Macau. In addition to the influence of local emission sources, TC is also affected by polluted continental air masses from the highly industrialized PRD region of mainland China. Thus, this site is capable of monitoring air pollutants transported from the inland PRD region and is suitable for assessing their impact on local air quality. The samples were collected on the rooftop of a building with a height of $15 \mathrm{~m}$.

\subsection{Measurement techniques}

\subsubsection{Continuous measurements of trace gases}

Measurement instruments were housed in a laboratory situated on the roof at both sites. Ambient air samples were drawn through a $10 \mathrm{~m}$ long PFA Teflon tube (outside diameter $12.7 \mathrm{~mm}$; inside diameter: $9.6 \mathrm{~mm}$ ). The sampling tube inlet was located $3 \mathrm{~m}$ above the rooftop of the laboratory, and the outlet was connected to a PFA-made manifold with a bypass pump drawing air at a rate of $15 \mathrm{~L} / \mathrm{min}$. Descriptions of the measurements of $\mathrm{O}_{3}, \mathrm{CO}, \mathrm{SO}_{2}$ and $\mathrm{NO}-\mathrm{NO}_{2}$ $\mathrm{NO}_{\mathrm{x}}$ can be found in Wang et al. (2003). In this study, continuous measurements of trace gases, including $\mathrm{O}_{3}$, NO$\mathrm{NO}_{2}-\mathrm{NO}_{\mathrm{x}}, \mathrm{CO}$ and $\mathrm{SO}_{2}$, were conducted from 22 October to 1 December 2007 at WQS, while at TC the hourly data of $\mathrm{O}_{3}, \mathrm{CO}, \mathrm{SO}_{2}$, and $\mathrm{NO}_{\mathrm{x}}$ were obtained from the website of the Hong Kong Environmental Protection Department (HKEPD) (http://www.epd.gov.hk). Detailed information about the measurements and quality control and assurance at the TC site can be found in the HKEPD report (HKEPD, 2007). Here, we briefly describe the measurements at WQS. Ozone was measured using a commercial UV photometric instrument (Thermo Environmental Instruments (TEI), model 49C) that had a detection limit of 2 ppbv and a 2-sigma (2-s) precision of 2 ppbv for a 2-min average. $\mathrm{CO}$ was measured with a gas filter correlation, nondispersive infrared analyzer (API, Model 300) with a heated catalytic scrubber to convert $\mathrm{CO}$ to carbon dioxide $\left(\mathrm{CO}_{2}\right)$ for baseline determination. $\mathrm{SO}_{2}$ was monitored by pulsed UV fluorescence (TEI, model 43S), with a detection limit of $0.06 \mathrm{ppbv}$ and 2 -s precision of $3 \%$ for ambient levels of 
10 ppbv (2-min average). $\mathrm{NO}$ and $\mathrm{NO}_{\mathrm{x}}$ were detected with a chemiluminescence $\mathrm{NO}-\mathrm{NO}_{2}-\mathrm{NO}_{\mathrm{x}}$ analyzer (Thermo Electron Corporation, Model $42 \mathrm{i}$ trace level). The analyzer has a detection limit of $0.05 \mathrm{ppbv}$. These analyzers were calibrated daily by injecting scrubbed ambient air (TEI, Model 111) and a span gas mixture. A NIST-traceable standard (ScottMarrin, Inc.) containing $156.5 \mathrm{ppmv} \mathrm{CO}( \pm 2 \%), 15.64 \mathrm{ppmv}$ $\mathrm{SO}_{2}( \pm 2 \%)$, and $15.55 \mathrm{ppmv} \mathrm{NO}( \pm 2 \%)$ was diluted using a dynamic calibrator (Environics, Inc., Model 6100). For the $\mathrm{O}_{3}, \mathrm{SO}_{2}, \mathrm{NO}$ and $\mathrm{NO}_{\mathrm{x}}$ analyzers, a data logger (Environmental Systems Corporation, Model 8816) was used to control the calibrations and to collect data, which were averaged to 1 -min values.

\subsubsection{Sampling and analyses of VOCs and carbonyls}

Ambient NMHC samples were collected using cleaned and evacuated 2-L electro-polished stainless steel canisters on selected days (26-27 Oct, 13 Nov, 15-17 Nov, 23 Nov, and 1 Dec). These potential high $\mathrm{O}_{3}$ episode days were selected for NMHCs and carbonyl sampling on the basis of weather prediction and meteorological data analysis, which were usually related to stronger solar radiation, weaker wind speed and less vertical dilution of air pollution, compared to non- $\mathrm{O}_{3}$ episode days. Details of the preparation and pre-conditioning of the canisters are described in Blake et al. (1994). During the sampling, a flow-controlling device was used to collect 1-h integrated samples. At both sampling sites, hourly NMHC samples were collected from 7 a.m. to 6 p.m. at $\mathrm{TC}$, and from $6 \mathrm{a} . \mathrm{m}$. to $6 \mathrm{p} . \mathrm{m}$. at WQS for the selected days. The samples were analyzed by an Entech Model 7100 Preconcentrator (Entech Instruments Inc., California, USA) coupled with a gas chromatography-mass selective detector (GC-MSD, Agilent 5973N). A HP-1 capillary column $(60 \mathrm{~m} \times 0.32 \mu \mathrm{m} \times 1.0 \mu \mathrm{m}$, Agilent Technologiea, USA) was used with helium as carrier gas. The GC oven temperature was initially held at $-50^{\circ} \mathrm{C}$ for $3 \mathrm{~min}$, after which it was increased to $10^{\circ} \mathrm{C}$ at $15^{\circ} \mathrm{C} \mathrm{min}^{-1}$, then to $120^{\circ} \mathrm{C}$ at $5^{\circ} \mathrm{C}, \mathrm{min}^{-1}$, and finally to $250^{\circ} \mathrm{C}$ at $10^{\circ} \mathrm{C} \mathrm{min}^{-1}$. The analysis was conducted after holding it at $250^{\circ} \mathrm{C}$ for $10 \mathrm{~min}$. The MSD was used in selected ion monitoring (SIM) mode and the ionization method was electron impacting (EI). The detection limit of aromatics is $0.003 \mathrm{ppbv}$, and that of other NMHCs is 0.005 ppbv.

Carbonyl samples were collected simultaneously at both sites on the same selected days. Samples were collected at $0.4-0.5 \mathrm{~L} / \mathrm{min}$ for $150 \mathrm{mins}$ using a carbonyl sampler (ALDEHYDE, UNIT \#7) by passing air through a silica cartridge impregnated with acidified 2, 4dinitrophenylhydrazine, which is very reactive toward carbonyls. $\mathrm{An}_{3}$ scrubber was connected to the inlet of the cartridge during each sampling to eliminate the impact of $\mathrm{O}_{3}$. About four carbonyl samples were collected during each sampling day. All cartridges were stored in a refrigerator at $-4^{\circ} \mathrm{C}$ after sampling. Each sampled cartridge was eluted
Table 1. The operating conditions of HPLC.

\begin{tabular}{ll}
\hline Column & Nava-Pak C18 $3.9 \times 150 \mathrm{~mm}$ \\
\hline Mobile phase & A: Water/Acetonitrile/Tetrahydrofuran $60 / 30 / 10$ \\
Gradient & B: Water/Acetonitrile 40/60 \\
Flow rate & $100 \%$ A for 2 min then a linear gradient from \\
& $100 \%$ A to $100 \%$ B in $18 \mathrm{~min}, 100 \%$ B for $4 \mathrm{~min}$ \\
Injection & $20 \mu \mathrm{L}$ \\
volume & \\
Detection & Absorbance at $360 \mathrm{~nm}$ \\
\hline
\end{tabular}

slowly with $5 \mathrm{~mL}$ of acetonitrile (ACN) into a $5 \mathrm{~mL}$ volumetric flask. A $20-\mu \mathrm{L}$ aliquot was injected into the HPLC system through an auto-sampler. The operating conditions of the HPLC are shown in Table 1 . Typically $\mathrm{C}_{1}-\mathrm{C}_{8}$ carbonyl compounds are measured effectively by this technique with a detection limit of $\sim 0.2 \mathrm{ppbv}$.

\subsubsection{Quality control and assurance for VOC and car- bonyl analyses}

Before sampling, all canisters were cleaned at least five times by repeatedly filling and evacuating humidified pure nitrogen gas. In order to check whether there was any contamination in the canister, we filled the evacuated canisters with pure $\mathrm{N}_{2}$ and stored them in the laboratory for at least 24 hours. These canisters were then checked by the same VOC analytical method to ensure that all the target compounds were not found or were under the method detection limit (MDL). In addition, duplicate samples were regularly collected to check the precision and reliability of the sampling and analytical methods.

The eluted species were identified and quantified by MSD. The identification of each compound was based on its retention time and fragmentation pattern. The quantification of target VOCs was accomplished using multi-point external calibration curves. The calibration curves were updated every day and were prepared using 1000 ppbv standard calibration gases (TO-14 gases, Spectra Gases Inc.) at five different diluted concentrations plus humidified zero air (0-40 ppbv). The standard gases were analyzed in the same way as the field samples.

Identification and quantification of carbonyl compounds were based on retention times and peak areas of the corresponding calibration standards, respectively. The instrument was calibrated using five standard concentrations covering the concentrations of interest for ambient samples. Excellent linear relationships $\left(R^{2}>0.998\right)$ were observed between the concentrations and responses for all carbonyls identified. Cartridge collection efficiency was determined with two cartridges in series, and over $98 \%$ of carbonyl compounds were found in the first cartridge. Relative percent differences (RPDs) for duplicate analysis were within $10 \%$. 


\subsubsection{Meteorological parameters}

Several meteorological parameters were simultaneously measured using a mini weather station (Vantage Pro2 ${ }^{T M}$, Davis Instruments Corp., USA) during the study period at WQS, including wind speed, wind direction, temperature, relative humidity, total ultraviolet radiation $(320-400 \mathrm{~nm})$ and global solar radiation. The meteorological data at TC were obtained from the HKEPD for the sampling period.

\subsection{Lagrangian trajectories and dispersion simulation}

Lagrangian backward simulations of trajectories and particles have been widely used in the analysis of field measurements to learn the history of the observed air masses (e.g., Stohl, 1998, 2005; Cooper et al., 2001). In the present work, we use the NOAA-HYSPLIT4.8 model to calculate backward trajectories at WQS and TC sites during the entire study period, and to carry out particle release simulation for episode days (Draxler and Rolph, 2003). Previous works (Zhang et al., 2009, Ding et al., 2009; Guo et al., 2009) have demonstrated that the backward particle release simulation, which considers the dispersion processes in the atmosphere, can identify the history of air masses well.

In this work, the trajectory and dispersion model was driven with the hourly output of Weather Research and Forecasting (WRF) model (V3.01, Skamarock et al., 2008). WRF was run in three nested domains with grid spacings of $27 \mathrm{~km}$, $9 \mathrm{~km}$, and $3 \mathrm{~km}$, respectively. The finest domain covers the whole PRD region. Grid nudging was adopted in the outmost domain to minimize integration errors. More details of the model configurations can be found in Jiang et al. (2008). For trajectory calculation, we run HYSPLIT model 2-day backward for both sites (TC and WQS) at every 3 hours at the ending point of $200 \mathrm{~m}$ above sea level. For particle dispersion simulation of episode days, 5000 air mass parcels were released from the two sites at target hours and the model was backwardly run to calculate the air mass history of transport and dispersion. Finally, the residence time for a thickness of $100 \mathrm{~m}$ above the surface, i.e. the so-called "footprint" retroplume (Stohl et al., 2003; Ding et al., 2009), was calculated to investigate the possible source regions for the studied episodes.

In addition, the trajectories were classified into different groups by using the Hierarchical Clustering Method to quantify the mean concentrations of air pollutants in each group (Ward, 1963). Assuming that $n$ trajectories are to be classified into $k$ groups: $G_{1}, G_{2}, \ldots, G_{k}, X_{i t}$ represents the trajectory $i$ in $G_{t}$, and $X$ is the mean trajectory of $G_{t}$. The deviation sum of squares $S_{t}$ in $G_{t}$ can be expressed as:

$S_{t}=\sum_{i=1}^{n_{t}}\left(X_{i t}-X\right)^{T}\left(X_{i t}-X\right)$
Here, $n_{t}$ is the number of trajectories in $G_{t}$. The total deviation sum of squares $S$ is expressed as:

$S=\sum_{t=1}^{k} S_{t}$

We first assume that each trajectory has its own group, i.e. there are $n$ groups. We then reduce the group number from $n$ to $n-1$. This will increase the total deviation sum of squares $S$. We selectively merge two groups each time to minimize the increase of $S$. This process is repeated until the group number has reduced from $n$ to $k$. In this study, the final group number $k$ is determined by the grouping performance.

$C_{i t}$ is the air pollutant concentrations associated with the trajectory $X_{i t}$ in group $G_{t}$. Hence, the mean air pollutant concentrations $C_{t}$ in group $G_{t}$ can be expressed as:

$$
C_{t}=\frac{1}{n_{t}} \sum_{i=1}^{n_{t}} C_{i t}
$$

\section{Results and discussion}

\subsection{General meteorological conditions}

The mean sea level pressure and wind field on $1000 \mathrm{hPa}$ for East Asia over the whole sampling period are shown in Fig. 2. The figure was made using NCEP FNL (final) data with a horizontal resolution of $1^{\circ} \times 1^{\circ}$ (http://dss.ucar. edu/datasets/ds083.2/). It shows that there was an intensive high-pressure system over Northern China, while Hong Kong and the inland PRD region were in front of the highpressure ridge. Due to the influence of the high-pressure system, the prevailing synoptic winds in Hong Kong and the inland PRD region were from the northeast. Statistical analysis of the ground meteorological observation data suggests that the wind speed at the coastal TC site $\left(1.95 \pm 0.06 \mathrm{~m} \mathrm{~s}^{-1}\right)$ was higher than that at the inland WQS site $\left(1.32 \pm 0.08 \mathrm{~m} \mathrm{~s}^{-1}\right)$, and the average wind direction was $97^{\circ}$ (degrees azimuth, $0^{\circ}$ means North) at TC and $54^{\circ}$ at WQS (Table 2). The differences in wind speed and wind direction at the two sites implied that the air masses of the two sites may have had different transport pathways. In contrast, no statistical differences were found for temperature and relatively humidity at the two sites, respectively (Table 2).

\subsection{Spatial distributions and chemical signatures of lo- cal and regional air masses}

\subsubsection{Spatial patterns of trace gases, total NMHCs and carbonyls}

In this study, a total of 928 hourly trace gas averages (i.e. $\mathrm{O}_{3}$, $\mathrm{NO}_{\mathrm{x}}, \mathrm{CO}, \mathrm{SO}_{2}$ ) were collected at TC, with 920 hourly samples collected at WQS, except for CO (432 counts). Table 3 illustrates the data counts, average values, $95 \%$ confidence 
Table 2. Statistics of meteorological parameters at the TC and WQS sites.

\begin{tabular}{lcccccccccc}
\hline Sites & \multicolumn{2}{c}{ Count } & \multicolumn{2}{c}{ Average } & \multicolumn{2}{c}{ Max value } & \multicolumn{2}{c}{ Min value } & \multicolumn{2}{c}{$95 \%$ confidence interval } \\
\hline & TC & WQS & TC & WQS & TC & WQS & TC & WQS & TC & WQS \\
Temperature $\left({ }^{\circ} \mathrm{C}\right)$ & 954 & 791 & 21.8 & 21.9 & 31.6 & 31.5 & 11.0 & 12.6 & 0.21 & 0.24 \\
Wind speed $\left(\mathrm{m} \mathrm{s}^{-1}\right)$ & 945 & 702 & 1.95 & 1.32 & 5.3 & 5.1 & 0.4 & 0.0 & 0.06 & 0.08 \\
Wind direction $\left({ }^{\circ}\right)$ & 945 & 682 & 96.8 & 57.4 & - & - & - & - & - & - \\
Relative humidity $(\%)$ & 947 & 800 & 65.6 & 66.3 & 97.0 & 96.0 & 18.0 & 26.2 & 0.97 & 1.12 \\
Solar radiation $\left(\mathrm{W} \mathrm{m}^{-2}\right)$ & 954 & 783 & $665^{*}$ & $585^{*}$ & 789 & 721 & - & - & 15.6 & 15.6 \\
\hline
\end{tabular}

* Average of the daily maximum solar radiation.

Table 3. Statistics of total NMHCs, total carbonyls and other trace gases at the TC and WQS sites.

\begin{tabular}{lcccccc}
\hline Units: ppbv & \multicolumn{2}{c}{ TC } & \multicolumn{2}{c}{ WQS } \\
\hline & Count & $\begin{array}{l}\text { Average } \pm 95 \% \\
\text { confidence interval }\end{array}$ & Max value & $\begin{array}{l}\text { Count confidence } \\
\text { interval }\end{array}$ & Average $\pm 95 \%$ & Max value \\
\hline $\mathrm{O}_{3}$ & 928 & $32 \pm 1$ & 139 & 920 & $40 \pm 3$ & 182 \\
$\mathrm{NO}_{\mathrm{x}}$ & 928 & $45 \pm 2$ & 179 & 920 & $31 \pm 2$ & 155 \\
$\mathrm{CO}$ & 928 & $574 \pm 13$ & 1204 & 432 & $1047 \pm 38$ & 2915 \\
$\mathrm{SO}_{2}$ & 928 & $9 \pm 0.3$ & 35 & 920 & $32 \pm 1$ & 167 \\
Total NMHCs & 96 & $26 \pm 3$ & 141 & 102 & $39 \pm 6$ & 237 \\
Total Carbonyls & 26 & $19 \pm 4$ & 52 & 32 & $43 \pm 6$ & 92 \\
\hline
\end{tabular}

intervals and maximum values of $\mathrm{O}_{3}, \mathrm{NO}_{\mathrm{x}}, \mathrm{CO}, \mathrm{SO}_{2}$, total NMHCs and carbonyls measured at the two sites during the study period. The mean mixing ratios of $\mathrm{O}_{3}, \mathrm{CO}$, and $\mathrm{SO}_{2}$ at the WQS site - 40, 1047, and 32 ppbv, respectively - were $1.3,1.8$, and 3.6 times those measured at TC site, respectively. However, the average $\mathrm{NO}_{\mathrm{x}}$ concentration was $31 \mathrm{ppbv}$ at WQS, only 0.68 times that at TC. The elevated $\mathrm{NO}_{\mathrm{x}}$ level at TC is likely due to high traffic density at TC and its upwind locations, and/or aircraft emission around the Hong Kong International Airport. The respective maximum mixing ratios of $\mathrm{NO}_{\mathrm{x}}, \mathrm{CO}$ and $\mathrm{SO}_{2}$ were 155, 2915 and $167 \mathrm{ppbv}$ at the WQS site, and 178, 1204 and 35 ppbv at the TC site.

For NMHCs, 96 and 102 ambient VOC samples were collected at TC and WQS, respectively. A total of $61 \mathrm{NMHC}$ species were quantified. The mean total NMHC mixing ratio was 34 and $40 \mathrm{ppbv}$ at TC and WQS, respectively. The maximum total NMHC mixing ratio was $141 \mathrm{ppbv}$ at TC, compared to $237 \mathrm{ppbv}$ at WQS. We further divided NMHCs into four groups, namely alkanes, alkenes, aromatics, and biogenic VOCs (mainly isoprene), of which the first three groups were mainly emitted from anthropogenic sources. When the contribution of each VOC group to the total NMHC abundance was calculated, it was found that alkanes accounted for most of the NMHC abundance both at TC $(63 \%)$ and WQS $(40 \%)$, respectively. Alkenes, aromatics, and biogenic VOCs accounted for 16, 19, and $2 \%$ at TC, respectively. On the other hand, alkenes, aromatics and biogenic VOCs contributed 20,39 and $0.7 \%$ to the total NMHCs at WQS, respectively. The total NMHC concentration and composition at WQS were similar to that at Xinken reported by Liu et al. (2008). The clear difference of the VOC composition at the TC and WQS sites suggested a difference in VOC sources. The high contribution of alkanes at TC may owe to widespread use of liquefied petroleum gas, whereas the high contribution of aromatics at WQS may be attributed to industrial emissions, which are mainly located in Dongguan, upwind of the WQS site. Liu et al. (2008) reported that about $52 \%$ of the total NMHCs in the atmosphere of Dongguan were aromatics.

For carbonyls, 26 and 32 ambient samples were simultaneously collected at TC and WQS, respectively. A total of 11 species of carbonyls were quantified and the average mixing ratios of total carbonyls at TC and WQS were 19 and 43 ppbv, respectively. Among the 11 species, formaldehyde was the most abundant compound at both sites, accounting for $40 \%$ at TC and $49 \%$ at WQS. Acetaldehyde and acetone accounted for 29 and $17 \%$ at WQS, respectively, whereas the proportions of acetaldehyde and acetone were basically the same at TC, accounting for 26 and $28 \%$, respectively. The average concentrations of formaldehyde, acetaldehyde and acetone measured at TC were much lower than the mean values observed at WQS. Compared to other studies, the mean levels of formaldehyde $(7.5 \pm 1.9 \mathrm{ppbv})$ and acetaldehyde $(4.9 \pm 1.1 \mathrm{ppbv})$ at TC were close to the 


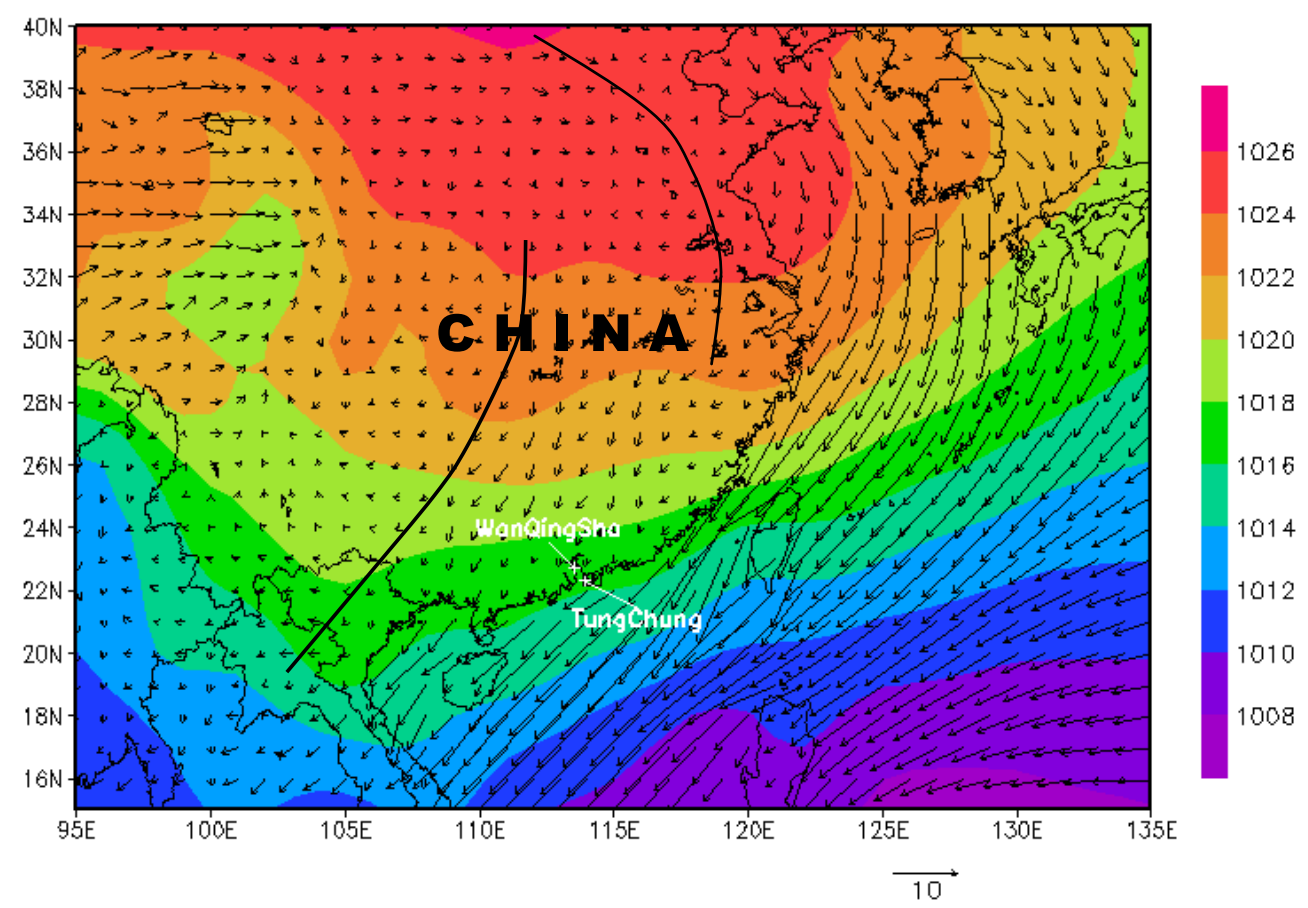

Fig. 2. Mean sea level pressure and wind field on $1000 \mathrm{hPa}$ between 22 October and 1 December 2007.

roadside values of Hong Kong in 2001-2002 (5.5-8.6 ppbv and 4.2-6.3 ppbv, respectively; Ho et al., 2006), indicating the importance of photochemical production at TC. On the other hand, the formaldehyde and acetaldehyde levels at WQS (20.9 $\pm 2.1 \mathrm{ppbv}$ and $12.6 \pm 2.6 \mathrm{ppbv}$, respectively) were much higher than those observed in Guangzhou (10.2 ppbv and 4.2 ppbv, respectively; Feng et al., 2005) during a study conducted from 15 July-20 September 2003. The high carbonyls concentrations at WQS could be caused by nearby sources like power plants (in Humen town of Dongguan, approximately $10 \mathrm{~km}$ to the southeast of $\mathrm{WQS}$ ), and by photochemical reactions, corresponding with the high $\mathrm{O}_{3}$ concentrations during the study period. Furthermore, as the sampling period in this study was different from those in previous studies (Feng et al., 2005; Ho et al., 2006), the elevated values found at TC and WQS might imply increased emissions of carbonyls in the inland PRD region in recent years.

\subsubsection{Characteristics of air masses in inland PRD and Hong Kong}

Carbon monoxide can be considered as an air pollution transport indicator due to its relatively long lifetime (months). A scatter plot (not shown) of CO measured at TC vs. WQS showed that the correlation coefficient was 0.40 . The poor correlation implies that the transport of air masses between Hong Kong and the inland PRD region during this study period may not be significant, or that local source influences are a dominant factor.
The concentration ratios of $\mathrm{SO}_{2}$ to $\mathrm{NO}_{\mathrm{x}}$ and of $\mathrm{CO}$ to $\mathrm{NO}_{\mathrm{x}}$ can provide signatures of the air masses arriving at each site. In this study, the $\mathrm{SO}_{2} / \mathrm{NO}_{\mathrm{x}}$ ratio was found to be $0.25 \pm 0.01 \mathrm{ppbv} / \mathrm{ppbv}$ at TC and $1.26 \pm 0.06 \mathrm{ppbv} / \mathrm{ppbv}$ at WQS, whereas the $\mathrm{CO} / \mathrm{NO}_{\mathrm{x}}$ ratio was $15.8 \pm 0.5 \mathrm{ppbv} / \mathrm{ppbv}$ at $\mathrm{TC}$ and $52.0 \pm 3.8 \mathrm{ppbv} / \mathrm{ppbv}$ at WQS. That is, the $\mathrm{SO}_{2} / \mathrm{NO}_{\mathrm{x}}$ and $\mathrm{CO} / \mathrm{NO}_{\mathrm{x}}$ ratios at WQS were much higher than those at TC $(p<0.001)$. This is because the air masses from mainland China are laden with relatively abundant $\mathrm{CO}$ and $\mathrm{SO}_{2}$ while the air masses in Hong Kong have high $\mathrm{NO}_{\mathrm{x}}$ levels (Kok et al., 1997; Wang, T. et al., 2001, 2005). Compared to previous studies, the $\mathrm{SO}_{2} / \mathrm{NO}_{\mathrm{x}}$ and $\mathrm{CO} / \mathrm{NO}_{\mathrm{x}}$ ratios at WQS (1.26 and 52.0, respectively) were 3-4 times higher than the values reported in upwind Guangzhou urban areas ( 0.4 and 11.9, respectively) (Zhang et al., 1998; Wang, X. M. et al., 2005). The higher ratios were probably caused by the lower $\mathrm{NO}_{\mathrm{x}}$ level due to photochemical conversion at this rural site.

The potential influence of local and regional air masses on the TC site can be therefore evaluated by $\mathrm{SO}_{2} / \mathrm{NO}_{\mathrm{x}}$ and $\mathrm{CO} / \mathrm{NO}_{\mathrm{x}}$ ratios. The $\mathrm{SO}_{2} / \mathrm{NO}_{\mathrm{x}}$ ratios at nine Hong Kong urban air quality monitoring stations were further investigated during the same period as this study. The ratio from October to December 2007 ranged from 0.12 to 0.29 (data from HKEPD website, http://www.epd.gov.hk), suggesting that the air masses at $\mathrm{TC}\left(\mathrm{SO}_{2} / \mathrm{NO}_{\mathrm{x}}\right.$ ratio: 0.25$)$ had similar chemical characteristics to that in Hong Kong urban areas. Similarly, we investigated the $\mathrm{CO} / \mathrm{NO}_{\mathrm{x}}$ ratios at Hong Kong urban air quality monitoring stations during the same period as well. Data at two stations were available, namely 

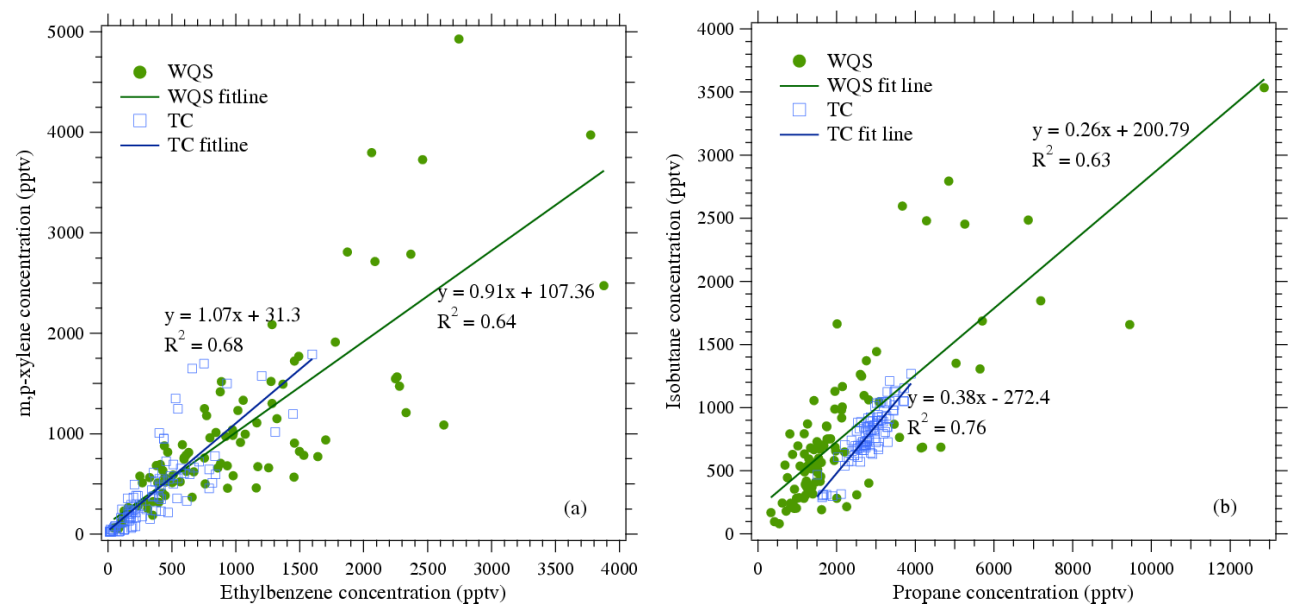

Fig. 3. Scatter plots of (a) $m, p$-xylene to ethylbenzene (b) $i$-butane to propane at TC and WQS during the VOC sampling period.

Tsuen Wan and Yuen Long, with ratios of $14.6 \pm 0.7$ and $20.6 \pm 0.6 \mathrm{ppbv} / \mathrm{ppbv}$, respectively, which were similar to the value at TC (15.8 ppbv/ppbv). Hence, both the $\mathrm{SO}_{2} / \mathrm{NO}_{\mathrm{x}}$ and $\mathrm{CO} / \mathrm{NO}_{\mathrm{x}}$ ratios suggest that the air masses at $\mathrm{TC}$ were mainly impacted by Hong Kong local emissions, in particular, the emissions of $\mathrm{NO}_{\mathrm{x}}$, and that there does not appear to have been a significant temporal change in these ratios during this decade for autumn values.

The ratios of VOCs with different photochemical lifetimes are useful tools to examine the atmospheric processes of air masses, including atmospheric transport and photochemical aging. Due to different lifetimes of two given VOC species, their ratio may change during the course of air mass transport. Using the ratio of a more reactive VOC to a less reactive VOC, a higher ratio indicates relatively little photochemical processing of the air mass and major impact from local emissions. On the other hand, a lower ratio is reflective of more aged VOC mixes and thus presumably that the VOCs were emitted from more distant sources. Comparisons of the ratios among sites can be used to estimate the relative ages of air parcels and help provide evidence of transport histories. Moreover, this ratio analysis can further indicate whether the site is dominantly affected by pollutants from local or regional sources. In this study, we compared the ratios of $m, p$-xylene/ethylbenzene and $i$-butane/propane at the two sites as a measure of atmospheric processing in different air masses (e.g. Grosjean et al., 1999; So and Wang, 2004; Guo et al., 2007). $m$, $p$-Xylene and ethylbenzene are mainly emitted from vehicles and solvent usage, whereas $i$ butane and propane have an origin of liquefied petroleum gas emission (Guo et al., 2007). $m, p$-Xylene is more reactive than ethylbenzene, with lifetimes about 1 and 2 days, respectively; $i$-butane also has a shorter lifetime than propane, with lifetimes of about 6 and 12 days, respectively. Figure 3 shows the scatter plots of (a) $m, p$-xylene to ethylbenzene and (b) $i$-butane to propane at TC and WQS. Clearly, TC had higher slopes than WQS for both VOC ratios, with an $m, p$ xylene/ethylbenzene ratio of 1.07 (versus 0.91 at WQS), and an $i$-butane/propane ratio of 0.38 (versus 0.26 at WQS). The results suggested that the air masses at WQS were more aged than that at TC, reflecting the higher importance of regional transport at the WQS site.

\subsection{Temporal variations}

\subsubsection{Day-to-day variations}

Figure 4 shows the day-to-day variations of $\mathrm{O}_{3}, \mathrm{NO}_{\mathrm{x}}, \mathrm{CO}$, $\mathrm{SO}_{2}$, and total NMHCs at the two sites, which were sometimes similar on consecutive days such as 25-26 October: high concentrations of $\mathrm{CO}, \mathrm{SO}_{2}, \mathrm{NO}_{\mathrm{x}}$ and $\mathrm{O}_{3}$ were observed at both sites on both days. In contrast, the day-to-day variations at the two sites showed differing daily patterns on other days such as 26-27 October: high levels of air pollutants were recorded on 26 October whereas the levels of air pollutants on 27 October were rather low. At the WQS site the maximum hourly average $\mathrm{O}_{3}$ concentration during the study reached $182 \mathrm{ppbv}$, whereas the peak hourly value was $139 \mathrm{ppbv}$ at the TC site (see Table 3). The number of $\mathrm{O}_{3}$ episode days (the daily maximum value exceeds the Hong Kong Air Quality Objective of 122 ppbv) reached 13 days out of 41 sampling days at WQS, compared to only 2 days at TC.

The concentrations of air pollutants have a close relationship with weather conditions, such as temperature, wind, solar radiation and so on (Wang et al., 2001, 2003; Wang and Kwok, 2003). Figure 5 also shows the time series of temperature, relative humidity, solar radiation and wind observed at the two sites during the study period. It can be seen that there were four clearly cooling processes, which happened on 30 October-1 November, 7-8 November, 18-19 November, and 26-29 November. These processes, with a decrease 


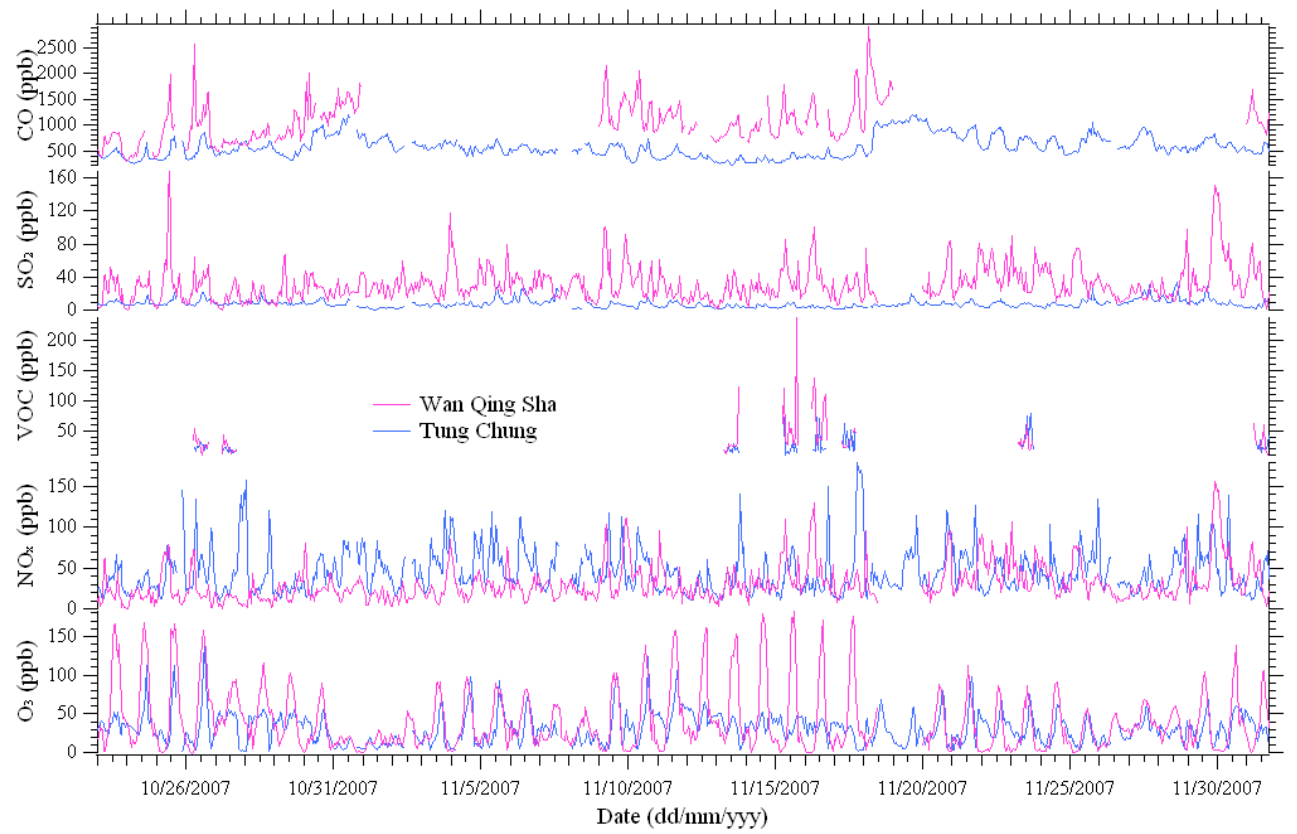

Fig. 4. Time series of trace gases and total NMHCs between 22 October and 1 December 2007.

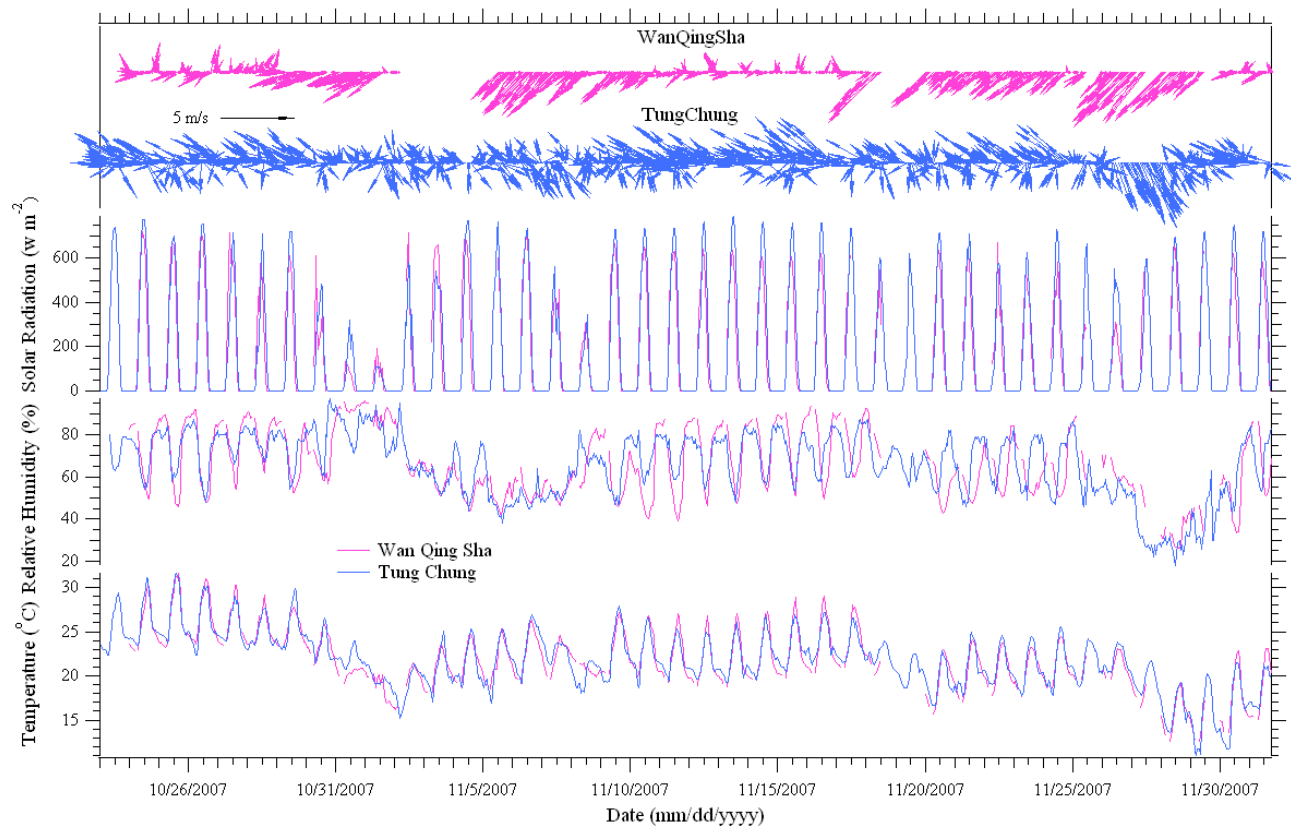

Fig. 5. Time series of the main meteorological factors between 22 October and 1 December 2007.

in air temperature, relative humidity and solar radiation, were generally associated with cold fronts, which brought dry and cold continental outflows to Southern China (Wang et al., 2003).

With the change of weather conditions, the concentrations of air pollutants changed correspondingly (see Figs. 4 and 5 ). Generally, when the northerly monsoons were enhanced, the $\mathrm{CO}$ levels were dramatically increased at both sites (for example, 30 October-1 November and 18-19 November). Chung et al. (1999) investigated the relationship between high CO episodes and synoptic conditions at a coastal station in Hong Kong and found similar features as well. In contrast to $\mathrm{CO}$, the $\mathrm{O}_{3}$ levels had a decreasing trend with enhanced northerly monsoons at both sites (for example, 30 October-1 
Table 4. Summary of synoptic weather conditions and the corresponding variations of air pollutants during the sampling period.

\begin{tabular}{|c|c|c|}
\hline Period & Synoptic weather conditions & Variation of pollutants \\
\hline 30 October $\sim 1$ November & $\begin{array}{l}\text { An intense northeast monsoon and a rain-band } \\
\text { over Southern China due to a high-pressure } \\
\text { system moving toward Eastern China which } \\
\text { brought cool and rainy weather to Hong Kong } \\
\text { and the inland PRD region. The temperature } \\
\text { decreased to about } 16^{\circ} \mathrm{C} \text { at night on } 1 \text { Novem- } \\
\text { ber, and the daily maximum solar radiation de- } \\
\text { creased to about } 180 \mathrm{~W} / \mathrm{m}^{2} \text {. }\end{array}$ & $\begin{array}{l}\mathrm{CO} \text { peaks reached } 1197 \mathrm{ppbv} \text { at } \mathrm{TC} \text { and } \\
1811 \mathrm{ppbv} \text { at } \mathrm{WQS} ; \mathrm{O}_{3} \text { concentrations de- } \\
\text { creased to a very low level at both sites. }\end{array}$ \\
\hline 2 3 November & $\begin{array}{l}\text { The weather turned fine again; a high-pressure } \\
\text { center was present near the Guizhou and Hu- } \\
\text { nan provinces, and the temperature began to } \\
\text { increase. }\end{array}$ & $\begin{array}{l}\mathrm{O}_{3} \text { levels increased slowly at both sites; } \mathrm{CO} \\
\text { concentrations had a decreasing trend. }\end{array}$ \\
\hline $7 \sim 8$ November & $\begin{array}{l}\text { It turned cloudy on } 8 \text { November as the cloud } \\
\text { band associated with Tropical Storm Peipah } \\
\text { over the South China Sea reached the South } \\
\text { China coast. The temperature decreased to } \\
\text { about } 21^{\circ} \mathrm{C} \text {. }\end{array}$ & $\begin{array}{l}\mathrm{O}_{3} \text { levels decreased slowly; the } \mathrm{O}_{3} \text { peaks at } \\
\mathrm{TC} \text { and WQS decreased from } 75 \text { and } 82 \mathrm{ppbv} \\
\text { (6 Nov) to } 29 \text { and } 59 \text { ppbv ( } 8 \text { November), re- } \\
\text { spectively. }\end{array}$ \\
\hline $9 \sim 17$ November & $\begin{array}{l}\text { On the south edge of the high-pressure system } \\
\text { located in North China, the weather was fine. }\end{array}$ & $\begin{array}{l}\mathrm{O}_{3} \text { peaks reached } 124(\mathrm{TC}) \text { and } 138 \mathrm{ppbv} \\
\text { (WQS) on } 10 \text { November } \mathrm{SO}_{2} \text { and } \mathrm{CO} \text { peaks } \\
\text { reached } 101 \text { and } 2158 \mathrm{ppbv} \text { at WQS, respec- } \\
\text { tively. }\end{array}$ \\
\hline 18 19 November & $\begin{array}{l}\text { Northerly monsoons were elevated due to } \\
\text { the moving high-pressure system, which was } \\
\text { present in Hunan province on } 19 \text { November. }\end{array}$ & $\begin{array}{l}\mathrm{CO} \text { mixing ratios were intensely elevated; } \\
\text { their peaks reached } 1204 \mathrm{ppbv} \text { at } \mathrm{TC} \text { and } \\
2915 \mathrm{ppbv} \text { at WQS. }\end{array}$ \\
\hline 26 29 November & $\begin{array}{l}\text { The northerlies strengthened on } 26 \text { November } \\
\text { when a surge of the intense northeast monsoon } \\
\text { reached Southern China. The weather became } \\
\text { progressively cool and very dry with the rel- } \\
\text { ative humidity falling below } 40 \% \text {. Tempera- } \\
\text { tures dropped to about } 14^{\circ} \mathrm{C} \text { on } 28 \text { November. }\end{array}$ & $\begin{array}{l}\mathrm{CO} \text { mixing ratios were elevated at TC. } \mathrm{SO}_{2} \\
\text { and } \mathrm{NO}_{\mathrm{x}} \text { both decreased to a low level at } \\
\text { WQS. } \mathrm{O}_{3} \text { levels had a decreasing trend at both } \\
\mathrm{TC} \text { and WQS. }\end{array}$ \\
\hline 30 November $\sim 1$ December & $\begin{array}{l}\text { The weather turned fine again; Hong Kong } \\
\text { and the inland PRD region were located near } \\
\text { the high-pressure ridge. }\end{array}$ & $\begin{array}{l}\mathrm{O}_{3} \text { peak reached } 138 \mathrm{ppbv} \text { at WQS, but re- } \\
\text { mained low at TC. }\end{array}$ \\
\hline
\end{tabular}

November and 7-8 November), perhaps due to the precipitation and the decrease in temperature and solar radiation. When the intense northerly monsoons were over, resulting in elevated temperature and solar radiation and a stable boundary layer, the photochemical reaction strengthened and the $\mathrm{O}_{3}$ level increased rapidly. In addition, due to the stable boundary layer and lower surface wind, the dispersion of primary air pollutants was reduced, resulting in elevated levels of $\mathrm{NO}_{\mathrm{x}}, \mathrm{SO}_{2}$, and $\mathrm{CO}$ (for example, 29-30 November), especially at WQS. This implies that the elevated $\mathrm{O}_{3}$ levels may be dominantly affected by local production. Table 4 summarizes the synoptic conditions and the corresponding variations of air pollutants levels. The $\mathrm{O}_{3}$ levels at the two sites during 11-17 November were very interesting. The $\mathrm{O}_{3}$ levels were fairly high at WQS (daily peaks $>150 \mathrm{ppbv}$ ) but rather low at TC (daily peaks $\sim 50 \mathrm{ppbv}$ ), although the distance between these two sites is only $62 \mathrm{~km}$. Similar phenomena were also observed during 23-29 October. This may be partly due to the relatively higher temperature, lower relative humidity, and much weaker wind speed during the daytime at WQS as well as stronger NMHC emissions in the inland PRD region. Detailed mechanisms for these phenomena will be further discussed in Sect. 3.5. In addition, whether $\mathrm{O}_{3}$ is VOC or $\mathrm{NO}_{\mathrm{x}}$ limited, and the local and regional contributions to $\mathrm{O}_{3}$ have been reported in another paper (Cheng et al., 2009). In brief, results of an observation-based model (OBM) support $\mathrm{O}_{3}$ production being VOC-limited in the PRD region. Furthermore, $\mathrm{O}_{3}$ and its precursors on some episode days originated from atmospheric transport, contrary to the predominantly local $\mathrm{O}_{3}$ production on other episode days. In this study, by further combining back trajectory analysis with diurnal variations of $\mathrm{O}_{3}$ production rate $\left(\mathrm{dO}_{3} / \mathrm{dt}\right)$ on the $13 \mathrm{O}_{3}$ episode days at WQS and 2 at TC, it was found that the $2 \mathrm{O}_{3}$ episodes at TC were mainly affected by regional transport, 


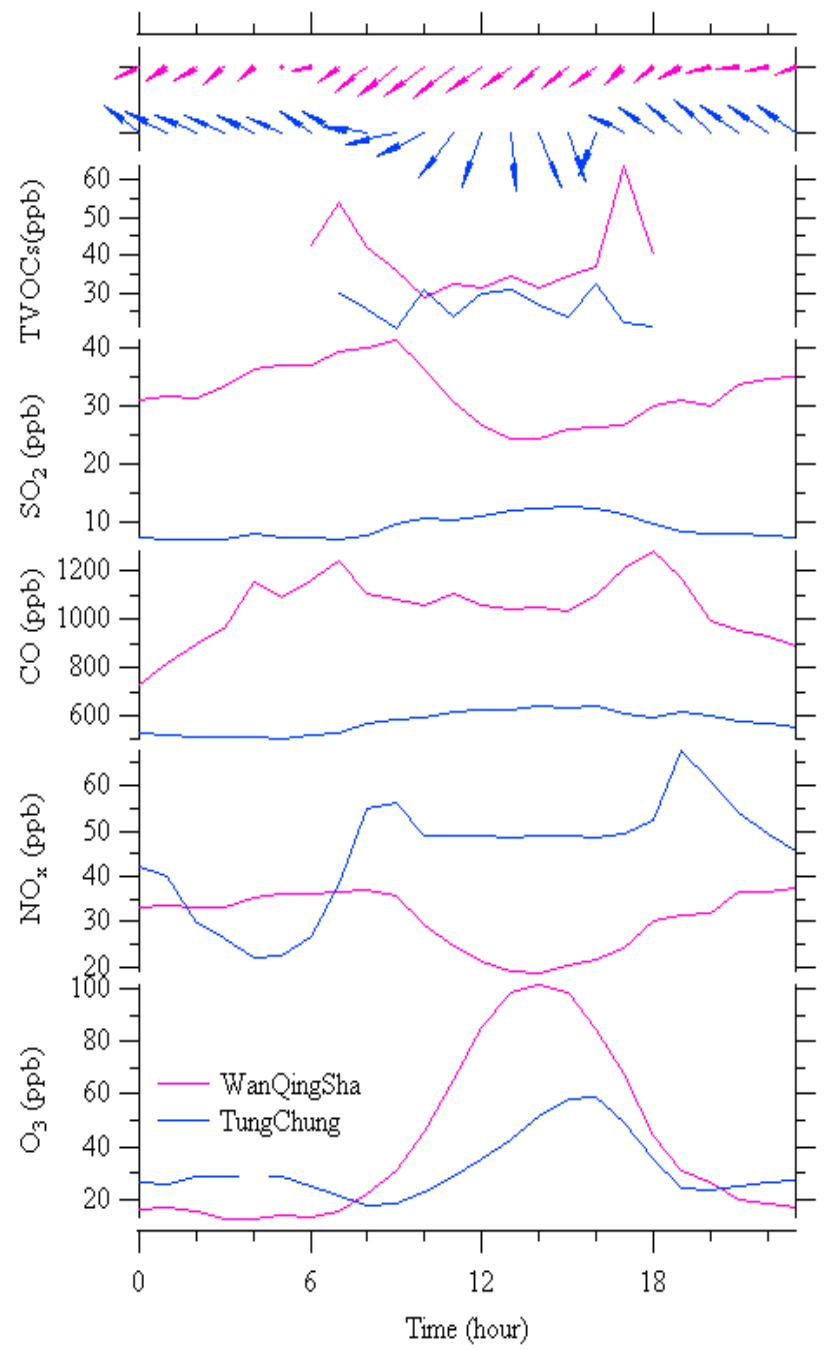

Fig. 6. Mean diurnal variations of total NMHCs, other trace gases and wind fields between 23 October to 1 December (total NMHCs were averaged using all VOC samples from 8 sampling days).

whereas 9 of the 13 episode days were dominated by local photochemical production at WQS. On the rest of the 13 episode days, the $\mathrm{O}_{3}$ mixing ratios were influenced by both local production and regional transport.

\subsubsection{Diurnal variations}

By analyzing the diurnal variations of air pollutants, information about the contributions of emissions and chemical and physical processes to a diurnal cycle can be obtained. Figure 6 shows the mean diurnal variations of trace gases, total NMHCs (8-day average), and wind fields at WQS and TC between 23 October and 1 December. A clear diurnal shift in wind direction was found at TC: the winds were southeasterly at night and then became more northerly with increased speeds during the daytime. However, the mean winds at WQS basically reflected the large-scale air flow from the northeast, with increased speeds in the morning and decreased speeds in the afternoon and at night.

In general, $\mathrm{O}_{3}$ showed a high peak in the afternoon and had relatively low concentrations at night at both sites (Fig. 6). However, different features were also observed at the two sites. Firstly, the maximum $\mathrm{O}_{3}$ level was much higher and the diurnal change was much faster at WQS than at TC, suggesting more significant photochemical production of $\mathrm{O}_{3}$ at WQS than that at TC. Secondly, the $\mathrm{O}_{3}$ concentration began to increase in the early morning (about 07:00) at WQS, whereas there was a low trough in early morning at TC followed by enhanced $\mathrm{O}_{3}$ beginning at about 09:00, likely due to high concentrations of NO in the morning which titrated some $\mathrm{O}_{3}$. Thirdly, the $\mathrm{O}_{3}$ concentrations at nighttime at TC ( $27 \pm 4 \mathrm{ppbv})$ were higher than those measured at WQS (18 \pm 3 ppbv), which was probably attributed to the constant transport of $\mathrm{O}_{3}$ to $\mathrm{TC}$ by southeasterly flows from the South China Sea where $\mathrm{O}_{3}$ was consumed less. This speculation was based on the fact that wind direction was from the southeast in the evening when the $\mathrm{O}_{3}$ level was higher at TC than that at WQS. Furthermore, early studies found that $\mathrm{O}_{3}$ levels gradually increased from the east to the west of Hong Kong when the South China Sea is downwind of Western Hong Kong (So and Wang, 2003). The average diurnal $\mathrm{O}_{3}$ difference (the mean daytime minus nighttime concentration) was $8 \pm 4$ ppbv and $41 \pm 6$ ppbv at TC and WQS, respectively (Table 5).

The diurnal variation of $\mathrm{NO}_{\mathrm{x}}$ at the TC site showed a typical urban profile (obvious bimodal structure) with peaks at about 09:00 and 19:00, respectively (Fig. 6). This observation is consistent with the traffic pattern of Hong Kong. However, much weaker $\mathrm{NO}_{\mathrm{x}}$ peaks were found at WQS as it was a rural site. As observed at many rural and coastal sites, reduced mid-daytime concentrations of $\mathrm{NO}_{\mathrm{x}}$ were found at both TC and WQS, which can be explained by high photochemical conversion and elevated vertical turbulence dilution. The diurnal patterns of $\mathrm{SO}_{2}$ and $\mathrm{CO}$ at the $\mathrm{TC}$ site were almost exactly the same, with a small and broad peak in the afternoon indicating the contribution of regional transport to $\mathrm{SO}_{2}$ and $\mathrm{CO}$ in Hong Kong by northerly winds. By contrast to TC, at the WQS site CO had an obvious bimodal structure profile, and $\mathrm{SO}_{2}$ had a high morning peak and a low afternoon concentration. The diurnal variation of total NMHCs at WQS showed two major peaks, namely in early morning and in late afternoon; at TC the peaks were much weaker and were not statistically different from the troughs. These observations show that VOC-limited $\mathrm{O}_{3}$ production is even more acute in the Hong Kong area than in the inland PRD region.

Figure 7 shows diurnal patterns of air pollutants observed on 26 and 27 October, which differed for primary species on high vs. low $\mathrm{O}_{3}$ pollution days. On 26 October the $\mathrm{O}_{3}$ level was very high, with peaks of $139 \mathrm{ppbv}$ at $\mathrm{TC}$ and 159 ppbv at WQS. In contrast, on 27 October the $\mathrm{O}_{3}$ concentrations remained relatively low and the afternoon $\mathrm{O}_{3}$ peaks were weak at both sites (95 and 55 ppbv at WQS and TC, 
Table 5. Mean concentrations of trace gases at daytime and nighttime and the diurnal difference.

\begin{tabular}{lllllll}
\hline Units: ppbv & \multicolumn{2}{c}{ Daytime* $^{*}$} & \multicolumn{2}{c}{ Nighttime $^{* *}$} & \multicolumn{2}{c}{ Daytime-Nighttime } \\
\hline & $\mathrm{TC}$ & WQS & $\mathrm{TC}$ & $\mathrm{WQS}$ & $\mathrm{TC}$ & $\mathrm{WQS}$ \\
$\mathrm{O}_{3}$ & $35 \pm 3$ & $59 \pm 7$ & $27 \pm 4$ & $18 \pm 3$ & $8 \pm 4$ & $41 \pm 6$ \\
$\mathrm{NO}_{\mathrm{x}}$ & $48 \pm 4$ & $27 \pm 3$ & $42 \pm 5$ & $34 \pm 5$ & $6 \pm 6$ & $-7 \pm 5$ \\
$\mathrm{CO}$ & $601 \pm 62$ & $1118 \pm 115$ & $545 \pm 55$ & $951 \pm 160$ & $58 \pm 33$ & $163 \pm 100$ \\
$\mathrm{SO}_{2}$ & $10 \pm 1$ & $32 \pm 3$ & $7 \pm 1$ & $33 \pm 5$ & $3 \pm 1$ & $-2 \pm 6$ \\
\hline
\end{tabular}

* From 06:00 to 18:00;

** from 19:00 to 05:00

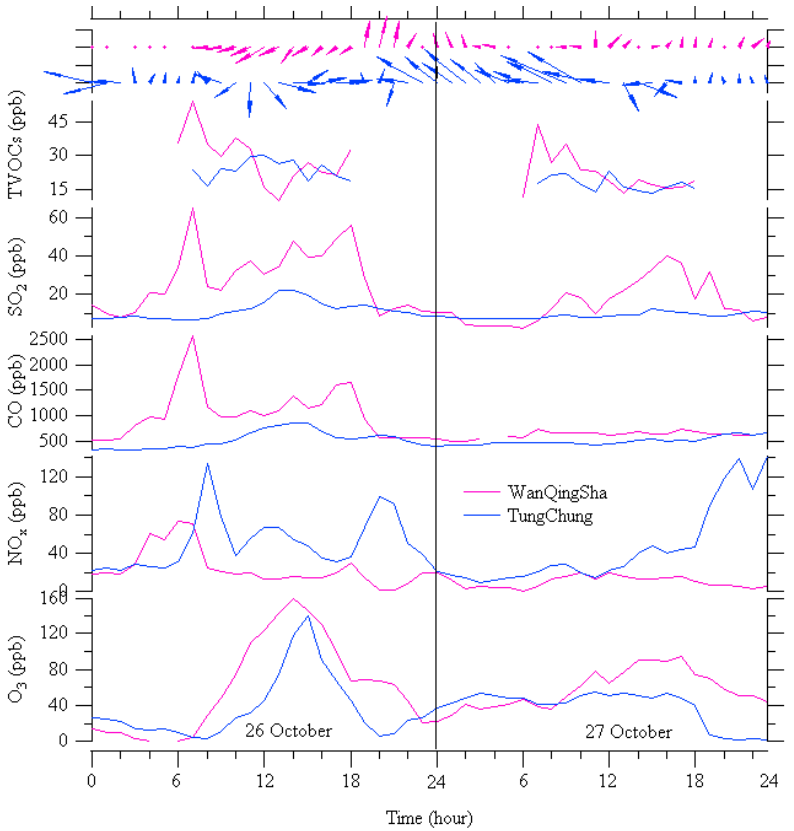

Fig. 7. Diurnal variation of total NMHCs, other trace gases and wind fields on 26 and 27 October.

respectively). The prevailing daytime winds on 26 October were northerly and their speeds were much smaller than typical values recorded at both sites (Fig. 6). However, on 27 October the winds turned southerly at the two sites, consistent with the arrival of less polluted maritime air.

At the TC site, the diurnal patterns of $\mathrm{NO}_{\mathrm{x}}, \mathrm{CO}$ and $\mathrm{SO}_{2}$ on 26 October were similar to the average profiles shown in Fig. 6, but with much sharper variations. On the other hand, on 27 October no daytime $\mathrm{CO}$ or $\mathrm{SO}_{2}$ peaks were observed at $\mathrm{TC}$ and the morning $\mathrm{NO}_{\mathrm{x}}$ peak was seriously reduced. These findings confirmed that the elevated $\mathrm{CO}$ and $\mathrm{SO}_{2}$ concentrations in the afternoon were due to regional transport by northerly winds. In addition, the difference in diurnal variation for total NMHCs between high $\mathrm{O}_{3}$ pollution and low $\mathrm{O}_{3}$ pollution days (i.e. a broader and higher peak near noon on 26 October than on 27 October) also revealed the regional transport influence.
At the WQS site, the $\mathrm{NO}_{\mathrm{x}}$ profile showed 2 peaks (the average value for the small afternoon peak was $30.2 \pm 1.3 \mathrm{ppbv}$, higher than the baseline level of $16.7 \pm 0.3 \mathrm{ppbv}$ ) on the high $\mathrm{O}_{3}$ pollution day ( 26 October), but these were $1-2 \mathrm{~h}$ earlier than those recorded at TC, whereas these peaks disappeared on 27 October and $\mathrm{NO}_{\mathrm{x}}$ concentrations fell. The patterns of $\mathrm{CO}$ and $\mathrm{SO}_{2}$ were virtually identical on 26 October, with both gases showing a sharp peak in early morning and a relatively lower peak in late afternoon. However, on 27 October, the $\mathrm{CO}$ concentrations remained at a low level without any obvious elevation during the daytime, whereas the $\mathrm{SO}_{2}$ concentrations became significantly enhanced in the afternoon. This indicates that the $\mathrm{CO}$ concentrations at WQS were basically attributed to regional transport, while the high $\mathrm{SO}_{2}$ concentration was partly due to local $\mathrm{SO}_{2}$ emission, perhaps from coal or biomass burning. On 26 October, total NMHCs at WQS had a high peak in early morning and concentrations remained high during the morning, followed by a sharp drop at noon. However, on 27 October, the low $\mathrm{O}_{3}$ pollution day, the total NMHC morning peak was reduced and the deep trough at noon disappeared, suggesting less transport and weaker source emissions in the morning and reduced photochemical consumption of NMHCs at noon.

\subsection{Air mass classification with trajectories}

To further investigate the regional transport of air pollutants, back trajectories were used to examine the typical air masses arriving at TC and WQS during this study period. From 25 October to 1 December, a total of 304 back trajectories (8 tracks per day) were calculated at each site, and then they were classified by using cluster analysis, which is a relatively objective method to investigate different transport patterns of air masses (Stohl, 1998). In this work, we classified the trajectories into 3 groups at both sites by using the Hierarchical Clustering Method (Ward, 1963) as shown in Fig. 8. The typical air mass patterns at TC and WQS were similar: the first trajectory was along the Eastern China coast (Track 1); the second originated from inland China (Track 2), passing over Fujian and Jiangxi provinces; and the third (Track 3) was also from inland China, but more northerly (over Jiangxi province) and with much higher transport speeds than 
Table 6. Proportion of air masses associated with each track and the corresponding concentrations of trace gases.

\begin{tabular}{lllllll}
\hline & \multicolumn{2}{c}{ Track 1 } & \multicolumn{2}{c}{ Track 2 } & \multicolumn{2}{c}{ Track 3 } \\
\hline & TC & WQS & TC & WQS & TC & WQS \\
Proportion (\%) & 44 & 25 & 17 & 41 & 39 & 34 \\
$\mathrm{O}_{3}$ (ppbv) & $35 \pm 3^{*}$ & $47 \pm 11$ & $31 \pm 7$ & $37 \pm 7$ & $27 \pm 3$ & $35 \pm 5$ \\
$\mathrm{NO}_{\mathrm{x}}$ (ppbv) & $40 \pm 5$ & $30 \pm 5$ & $48 \pm 7$ & $37 \pm 4$ & $49 \pm 4$ & $25 \pm 4$ \\
$\mathrm{CO}$ (ppbv) & $470 \pm 30$ & $894 \pm 64$ & $648 \pm 45$ & $1232 \pm 113$ & $680 \pm 37$ & $1351 \pm 153$ \\
$\mathrm{SO}_{2}$ (ppbv) & $8 \pm 1$ & $27 \pm 4$ & $9 \pm 1$ & $38 \pm 4$ & $11 \pm 1$ & $31 \pm 3$ \\
Total NMHCs (ppbv) & $22 \pm 5$ & $40 \pm 9$ & $30 \pm 15$ & $30 \pm 5$ & - & - \\
\hline
\end{tabular}

${ }^{*}$ Mean $\pm 95 \%$ confidence interval.

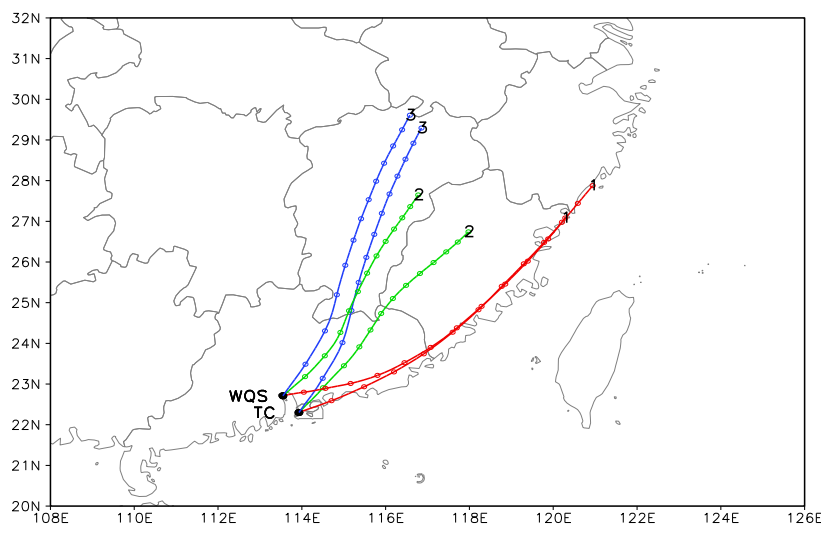

Fig. 8. Three typical back trajectories for each site at the $200 \mathrm{~m}$ height level.

Track 2. The proportion of air masses associated with each track and the corresponding concentrations of air pollutants are shown in Table 6. At TC, the air masses were mainly from Track 1 (44\%), followed by Track $3(39 \%)$ and Track 2 (17\%). By comparison, the air masses arriving at WQS were mainly from Track 2 (41\%), then Track 3 (34\%) and Track 1 $(25 \%)$. These results confirm the discussion in Sect. 3.1 that the air masses sources of the two sites differed somewhat.

As anticipated at TC, air masses from Track 1 had the lowest concentrations for primary pollutants (i.e. $\mathrm{NO}_{\mathrm{x}}, \mathrm{CO}$, $\mathrm{SO}_{2}$ ), and those from Track 3 had the highest concentrations of trace gases $(p<0.01)$. In contrast, the mean $\mathrm{O}_{3}$ concentration for Track $1(35 \pm 3$ ppbv) was significantly higher than that for Track 3 (27 \pm 3 ppbv) $(p<0.01)$. Inspecting the corresponding times of the Track 1 and Track 3 air masses, we found that the transport pathways of air masses were mainly dominated by Track 3 when the northerly monsoons were elevated, while Track 1 air masses were generally observed under fine weather conditions, i.e. with stronger solar radiation. It should be pointed out that these results were from the case of averaged concentration. The particle release simulations (Sect. 3.5) suggest an important role of inland anthropogenic emissions to the afternoon ozone episode at the TC site.
At WQS, Track 2 air masses had the highest concentrations of $\mathrm{NO}_{\mathrm{x}}(37 \pm 4 \mathrm{ppbv})$ and $\mathrm{SO}_{2}$ (38 \pm 4 ppbv), which were significantly higher than the concentrations of Track $3(p<0.05)$. The higher $\mathrm{NO}_{\mathrm{x}}$ and $\mathrm{SO}_{2}$ concentrations were most likely caused by chimney emissions of the power plant in Humen town of Dongguan, because Track 2 passes over the power plant area (labeled in Fig. 1). As was the case with TC, the air masses from Track 1 (i.e. the coastline) had the lowest concentrations of CO ( $894 \pm 64 \mathrm{ppbv})$ compared to Tracks 2 and $3(p<0.001)$, and the CO concentrations from Track 2 and Track 3 had no obvious difference $(p=0.26)$, indicating strong transport influences of $\mathrm{CO}$ from Eastern China regions. For $\mathrm{O}_{3}$, there were no statistical differences among the three tracks, further suggesting that $\mathrm{O}_{3}$ levels were dominantly affected by local production and/or sub-regional transport.

In contrast to the trace gases $\mathrm{CO}, \mathrm{SO}_{2}, \mathrm{NO}_{\mathrm{x}}$ and $\mathrm{O}_{3}$, the NMHCs were manually monitored for 8 sampling days within the study period. All samples were found to originate from Track 1 and Track 2, and no samples were observed from Track 3. Furthermore, because of relatively small sample size there was no statistical difference in NMHC concentration between the two tracks at both sites $(p>0.05)$. In order to obtain a more detailed signature of NMHCs in different air masses, much a finer back trajectory analysis was conducted to better understand the influence of regional transport on NMHCs. Nine-km resolution WRF output data were used in the HYSPLIT model, and 12-hour back trajectories at a $50 \mathrm{~m}$ height level were calculated for each hour during the VOC sampling period at both sites. Four groups of air masses were identified at each site, namely, Tracks A, B, C, and D (Fig. 9). The corresponding concentrations of NMHCs for each track were calculated as well (Table 7).

At the TC site, the air masses from Track $\mathrm{C}$ (passing over the inland region) had a higher total NMHC concentration than air masses from Tracks B and D $(p<0.05)$, which originated from the coast and the South China Sea, respectively, suggesting the significant influence of emission from the inland PRD region (mainly the northeastern part, i.e. Huizhou and Shenzhen) on NMHC levels at TC (Table 7). Further inspection of the anthropogenic NMHCs 
Table 7. Proportion of each air mass associated with each track and the corresponding concentrations of NMHCs during the VOC sampling period.

\begin{tabular}{lllllllll}
\hline & \multicolumn{3}{c}{ Track A } & \multicolumn{2}{c}{ Track B } & \multicolumn{2}{c}{ Track C } & \multicolumn{2}{c}{ Track D } \\
\hline & TC & WQS & TC & WQS & TC & WQS & TC & WQS \\
Proportion (\%) & 18 & 55 & 65 & 9 & 11 & 24 & 6 & 12 \\
Total NMHCs (ppbv) & $27.8 \pm 6.5$ & $42.5 \pm 9.2$ & $23.2 \pm 3.2$ & $22.2 \pm 7.5$ & $42.6 \pm 12.7$ & $42.6 \pm 15.1$ & $22.6 \pm 2.1$ & $30.8 \pm 6.3$ \\
Alkene (ppbv) & $4.9 \pm 0.6$ & $8.2 \pm 0.7$ & $3.9 \pm 0.2$ & $5.8 \pm 0.8$ & $3.8 \pm 0.8$ & $7.7 \pm 1.6$ & $3.5 \pm 0.6$ & $8.3 \pm 1.3$ \\
Alkane (ppbv) & $15.6 \pm 3.3$ & $15.8 \pm 1.8$ & $14.5 \pm 2.0$ & $12.5 \pm 6.1$ & $30 \pm 10.7$ & $17.6 \pm 6.1$ & $15.3 \pm 2.0$ & $14.5 \pm 3.5$ \\
Aromatic (ppbv) & $6.5 \pm 3.2$ & $18.3 \pm 8.7$ & $4.0 \pm 1.3$ & $3.6 \pm 1.1$ & $6.7 \pm 2.2$ & $17.0 \pm 8.5$ & $3.7 \pm 0.7$ & $7.7 \pm 2.3$ \\
\hline
\end{tabular}

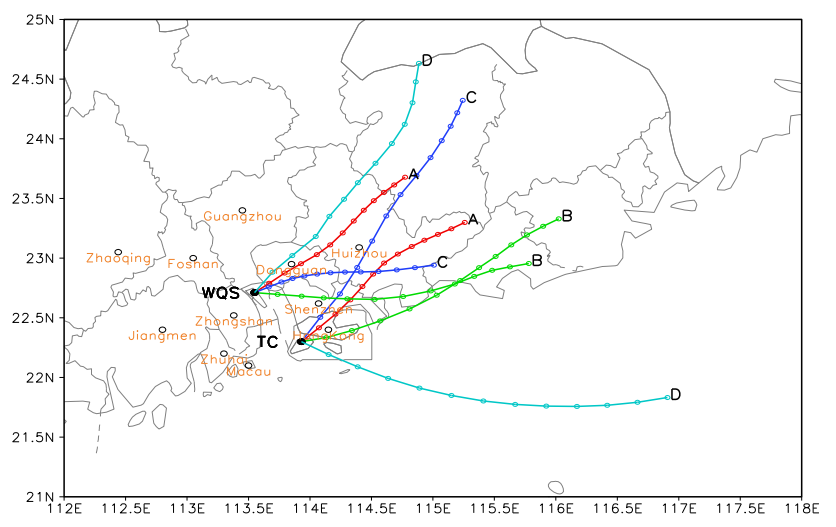

Fig. 9. Four typical back trajectories for each site at the $50 \mathrm{~m}$ height level during the VOC sampling period.

(i.e. alkenes, alkanes and aromatics) shows that the concentrations of alkanes for Track $\mathrm{C}$ were much higher than for Tracks B and D, mainly due to the contribution of 2methylpentane, 3-methylpentane, $n$-hexane, and methylcyclopentane, with mean concentrations 4-6 times those for Tracks B and D. In contrast, the total NMHC concentration for Track A $(27.8 \pm 6.5 \mathrm{ppbv})$ was similar to that for Tracks B and D, although Track A also originated from the inland region. Its value was between the levels for Track

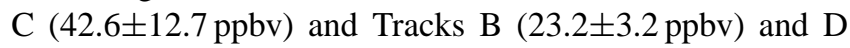
$(22.6 \pm 2.1 \mathrm{ppbv})$, perhaps due to the fact that the air masses from Track A were intersected by air masses from the inland region and the Southern China coast. However, the concentration of alkenes for Track A $(4.9 \pm 0.6 \mathrm{ppbv})$ was significantly higher than that for Tracks B $(3.9 \pm 0.2 \mathrm{ppbv})$ and $\mathrm{D}$ (3.5 $\pm 0.6 \mathrm{ppbv})$.

At the WQS site the concentrations of total NMHCs, alkanes, alkenes and aromatics in Track A were similar to those in Track C (both over Dongguan and Huizhou). The concentrations of total NMHCs for these two tracks were significantly higher than those for Track B $(p<0.05)$, which came along the coast and passed over the north of Shenzhen, indicating the influence of Dongguan and Huizhou on the WQS site. Further inspection found that the higher total NMHCs in
Tracks $\mathrm{A}$ and $\mathrm{C}$ were mainly attributed to the higher aromatic concentrations. For example, the mean concentrations of toluene, ethylbenzene, $m / p$-xylene, and $o$-xylene for Track C were 3-6 times those for Track B. This result also confirms the discussion in Sect. 3.2.1 that Dongguan made a significant contribution to aromatics at WQS.

\subsection{Sub-regional transport and its impact on ozone pol- lution in Western Hong Kong}

One of the major motivations for this concurrent two-site experiment was to study the transport of sub-regional pollution. Early trajectory analyses have shown the differences in transport pathways and chemical characteristics of the air masses at the two sites. However, the trajectory calculation did not consider the influence of turbulent mixing, though it could be very important for small-scale air pollution transport and dispersion. In this section, we used backward particle release simulation to further investigate the impact of sub-regional transport on ozone pollution.

Here we mainly focused on the multi-day episodes observed on 9-17 November, 2007. As shown in Fig. 4, there was severe multi-day ozone pollution at WQS with daily maximum $\mathrm{O}_{3}$ levels exceeding $100 \mathrm{ppbv}$ for 9 days. However, at the TC site, the ozone episodes were only observed on the first three days (i.e. 9-11 November). An investigation of the weather charts suggests that the synoptic condition during this period was characterized by a stagnant high pressure system which controlled Southern China, causing consistently strong solar radiation in the study region (see also Table 4). To illustrate the difference in the history of the afternoon air masses at the two sites, Fig. 10 gives the results from the particle release simulations for TC and WQS at 15:00 LT on 9, 10, 12 and 16 November. Here we only show the "footprint" concentrations (i.e. $100 \mathrm{~m}$ above ground level) to see the potential source regions. The figure clearly shows that at the TC site, there was more inland transport on the first several days, particularly from the nearby Shenzhen urban area, and then the transport pathway of the air masses turned more easterly from the inland to the coast. Under such situations, TC became downwind of the Hong Kong urban 
15:00 Nov 9, 2007

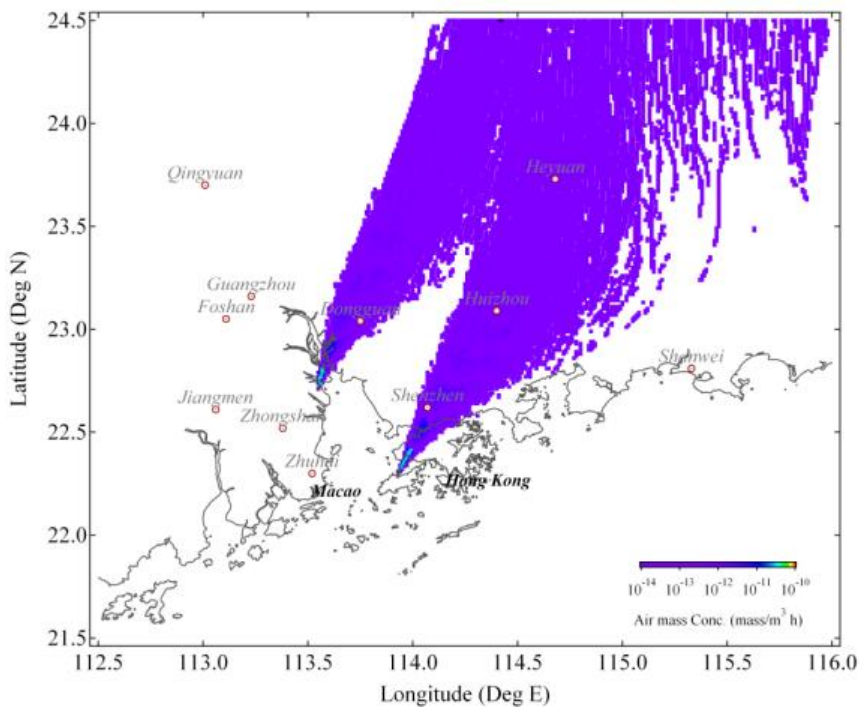

15:00 Nov 12, 2007

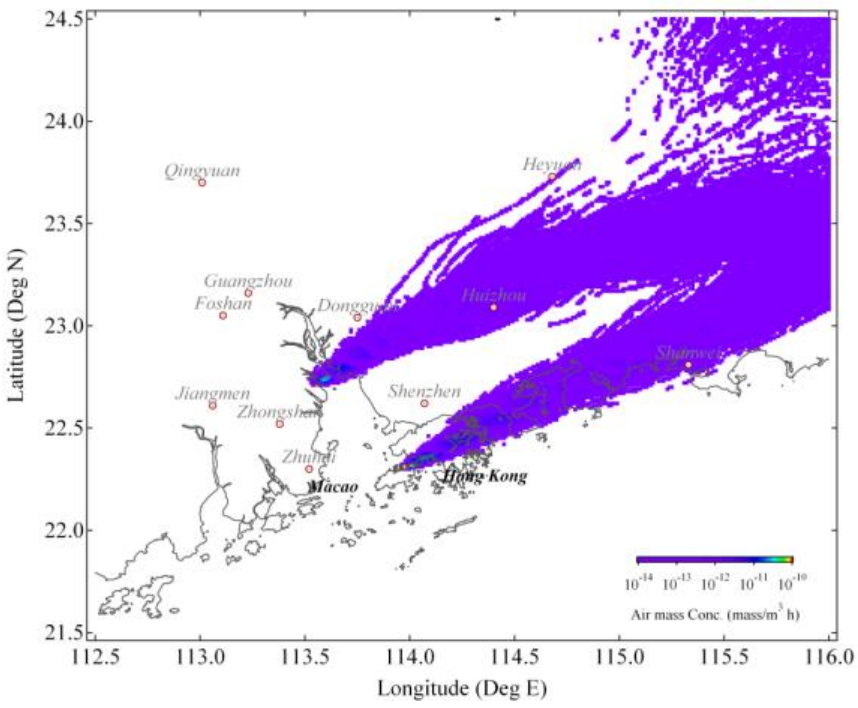

15:00 Nov 10,2007

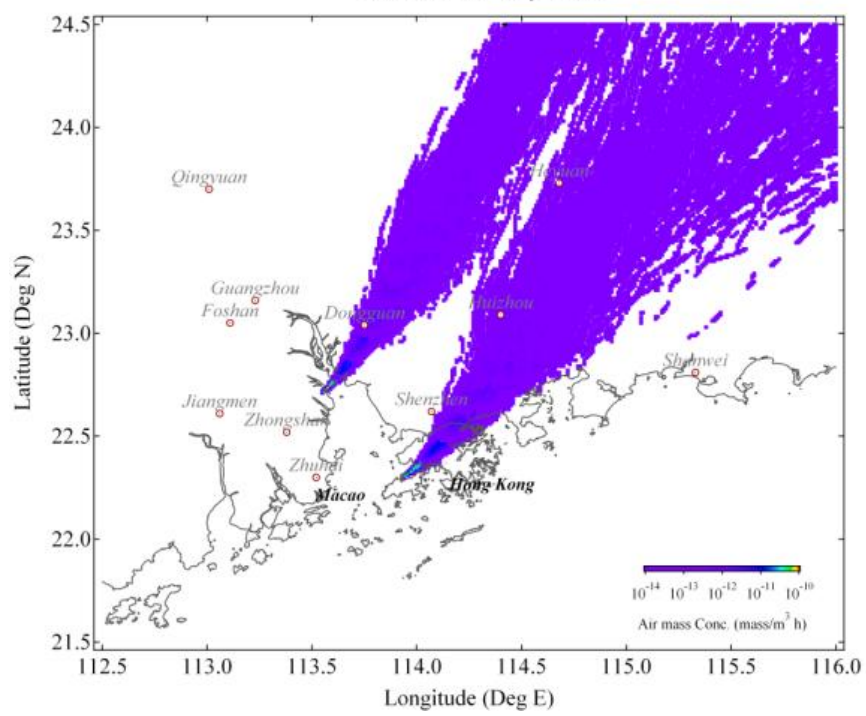

15:00 Nov 16, 2007

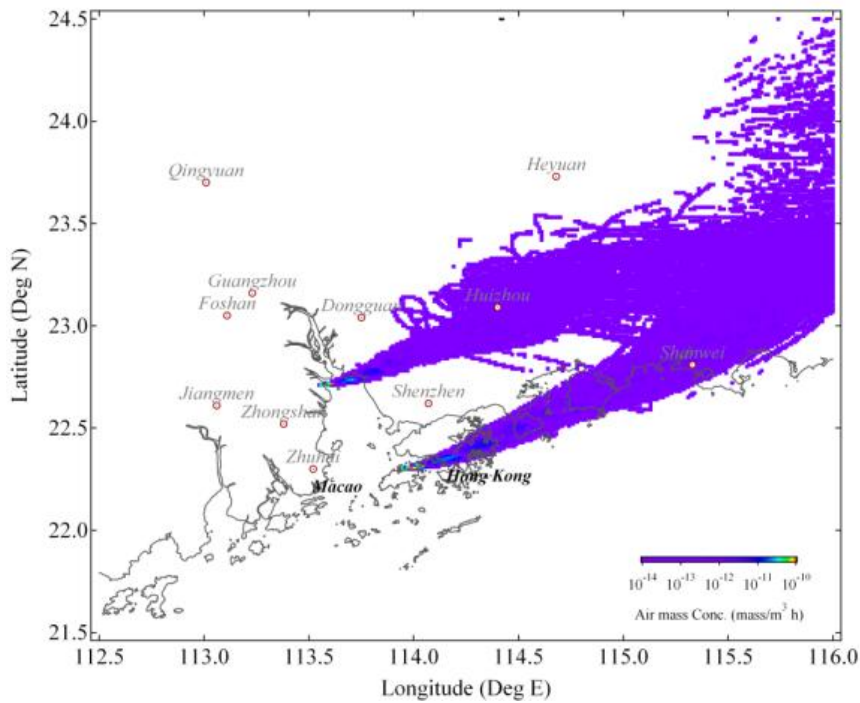

Fig. 10. (a-d) Distribution of air mass concentrations (in unit of mass $/ \mathrm{m}^{3} \mathrm{~h}$ ) within surface $100 \mathrm{~m}$ from HYSPLIT Lagrangian backward particle release simulation for WQS and TC at 15:00 LT on 9-10, 12 and 16 November 2007.

area, whereas the WQS site was consistently downwind of Dongguan and Huizhou. Hence, with the condition of strong solar radiation, high anthropogenic emissions from this area (i.e. Dongguan, Shenzhen and Huizhou) caused high photochemical pollution for the entire period at WQS and the first three days at TC, suggesting that large scale synoptic weather, affecting regional/sub-regional transport, plays an important role in ozone pollution in west Hong Kong in autumn. The cross-boundary transport makes it much difficult to formulate an effective air pollution control policy for local governments. An inseparable collaboration between inland PRD and Hong Kong governments is needed to jointly solve the photochemical pollution in this region. The retroplume pattern in Fig. 10 also shows that the plume width was much boarder in the early stage of the episode period, suggesting a small wind speed and a high horizontal dispersion. It is noteworthy that the method used in this study only accounted for general transport and dispersion patterns for this $\mathrm{O}_{3}$ episode event. A more detailed analysis with 3-D chemical transport model will be carried out in the future. 


\section{Summary and conclusions}

We analyzed measurement data collected concurrently at a site in the inland PRD region (WQS) and a site in greater Hong Kong (TC). The average levels of air pollutants at the WQS site were much higher than those at the TC site, with the exception for $\mathrm{NO}_{\mathrm{x}}$. The respective mean mixing ratios ( $\pm 95 \%$ confidence interval) at WQS and TC were $40 \pm 2$ and $32 \pm 1 \mathrm{ppbv}\left(\mathrm{O}_{3}\right), 31 \pm 2$ and $45 \pm 2 \mathrm{ppbv}\left(\mathrm{NO}_{\mathrm{x}}\right), 1047 \pm 38$ and $574 \pm 13$ ppbv (CO), $32 \pm 1$ and $9 \pm 0.3 \mathrm{ppbv}\left(\mathrm{SO}_{2}\right), 40 \pm 6$ and $33 \pm 4$ ppbv (total NMHCs), and $43 \pm 6$ ppbv and $19 \pm 4$ ppbv (total carbonyls). The relatively high CO levels at WQS were attributed to regional emissions, and the high $\mathrm{SO}_{2}$ levels at WQS were attributed to local power plant emissions in $\mathrm{Hu}-$ men of Dongguan. By comparison, the high traffic density in Hong Kong contributed to the elevated $\mathrm{NO}_{\mathrm{x}}$ levels at TC. In addition, the results from this study indicate that carbonyl levels in the region have increased in recent years.

Northerly monsoons bring cold, dry air from the inner Asian continent to the PRD region. Whereas elevated CO levels were generally observed at both sites when northerly monsoons were enhanced, the monsoons were associated with a decreasing $\mathrm{O}_{3}$ trend. Instead, $\mathrm{O}_{3}$ episodes usually occurred when weather systems were relatively stable. Analysis of the synoptic weather conditions and variations of air pollutants indicated that high $\mathrm{O}_{3}$ levels were mainly attributed to local photochemical production. However, significant differences in diurnal variations of air pollutants were also observed at the two sites, indicating different local and regional contributions. In particular, ozone episodes were stronger and more frequent at WQS than TC. During the sampling period the daily maximum $\mathrm{O}_{3}$ value exceeded 122 ppbv 13 times at WQS compared to 2 times at TC, with maximum $\mathrm{O}_{3}$ levels of $182 \mathrm{ppbv}$ at WQS vs. $139 \mathrm{ppbv}$ at TC. Diurnal variations of $\mathrm{O}_{3}$ showed higher nighttime levels of $\mathrm{O}_{3}$ at TC than at WQS as well as more photochemical activity at WQS than TC. At each site, remarkable differences in diurnal variations were also found between high and low $\mathrm{O}_{3}$ pollution days. An important conclusion from this work is that Hong Kong is more acutely VOC-limited than the inland PRD region.

A detailed look at the NMHCs showed that the composition of NMHCs and carbonyls were different at the two sites, with relatively higher levels of alkanes at TC that were attributed to LPG usage, and relatively higher levels of aromatics at WQS that were due to industry. Various air pollutant ratios $\left(\mathrm{SO}_{2} / \mathrm{NO}_{\mathrm{x}}, \mathrm{CO} / \mathrm{NO}_{\mathrm{x}}, m, p\right.$-xylene/ethylbenzene, $i$-butane/propane) further suggested that air masses arriving at TC were mainly affected by local emissions superimposed by regional transport, whereas the air at WQS was highly influenced by regional emissions and was therefore more aged. Indeed, backward trajectory analysis showed that air masses arriving at these two sites had different transport pathways. This finding was corroborated by higher wind speeds and different wind directions at TC than WQS. The back trajecto- ries showed that air masses arriving at WQS were mainly affected by inland China, including Dongguan and Huizhou, whereas air masses arriving at TC were primarily from the East China Coast, which brought lower levels of pollutants to Hong Kong. However, the anthropogenic emissions in Eastern PRD (e.g. Shenzhen urban area) could be transported to Western Hong Kong and cause serious photochemical pollution there.

Acknowledgements. The authors thank Steven Poon, Zengyue $\mathrm{Li}$, and Wai Chun Tse for their help with sample collections. The project is supported by the Research Grants Council of the Hong Kong Special Administrative Region (Project No. PolyU 5163/07E), the Postgraduate Studentship (RGYE) and the Research Grant (87PK) of the Hong Kong Polytechnic University, and the National Key Basic Research Support Foundation of China (Grant No. 2006CB403706, 2006CB403703).

Edited by: T. Karl

\section{References}

Aneja, V. P., Kim, D. S., Das, M., and Hartsell, B. E.: Measurements and analysis of reactive nitrogen species in the rural troposphere of southeast United States: southern oxidant study site sonia, Atmos. Environ., 30(4), 649-659, 1996.

Barletta, B., Meinardi, S., Simpson, I. J., Zou, S. C., Rowland, F. S., and Blake, D. R.: Ambient mixing ratios of nonmethane hydrocarbons (NMHCs) in two major urban centers of the Pearl River Delta (PRD) region: Guangzhou and Dongguan, Atmos. Environ., 42, 4393-4408, 2008.

Blake, D. R., Smith Jr., T. W., Chen, T.-Y., Whipple, W. J., and Rowland, F. S.: Effects of biomass burning on summertime nonmethane hydrocarbon concentrations in the Canadian wetlands, J. Geophys. Res.-Atmos., 99(D1), 1699-1719, 1994.

Chan, L. Y., Chan, C. Y., and Qin, Y.: Surface ozone pattern in Hong Kong. J. Appl. Meteorol., 37 (10), 1153-1165, 1998a.

Chan, L. Y., Liu, H. Y., and Lam, K. S.: Analysis of the seasonal behavior of tropospheric ozone at Hong Kong, Atmos. Environ., 32(2), 159-168, 1998b.

Chan, L. Y., Chu, K. W., Zou, S. C., Chan, C. Y., Wang, X. M., Barletta, B., Blake, D. R., Guo, H., and Tsai, W. Y.: Characteristics of nonmethane hydrocarbons (NMHCs) in industrial, industrialurban, and industrial-suburban atmospheres of the Pearl River Delta (PRD) region of south China, J. Geophys. Res.-Atmos., 111, D11304, doi:10.1029/2005JD006481, 2006.

Cheng, H. R., Guo, H., Wang, X. M., Saunders, S. M., Lam, S. H. M., Jiang, F., Wang, T. J., Lee, S. C., and Ho, K. F.: On the relationship between ozone and its precursors in the Pearl River Delta: Application of an Observation-Based Model (OBM), Environ. Sci. Poll. Res., accepted, 2009.

Chung, K. K., Chan, J. C. L., Ng, C. N., Lam, K. S., and Wang, T.: Synoptic conditions associated with high carbon monoxide episodes at a coastal station in Hong Kong, Atmos. Environ., 33, 3087-3095, 1999.

Cooper, O. R., Moody, J. L., Parrish, D. D., Trainer, M., Ryerson, T. B., Holloway, J. S., Hubler, G., Fehenfeld, F. C., Oltmans, S. J., and Evans, M. J.: Trace gas signatures of the airstreams within 
North Atlantic cyclones: Case studies from the North Atlantic Regional Experiment (NARE '97) aircraft intensive, J. Geophys. Res., 106(D6), 5437-5456, 2001.

Ding, A. J., Wang, T., Zhao M., Wang, T. J., and Li, Z. K.: Simulation of sea-land breezes and a discussion of their implications on the transport of air pollution during a multi-day ozone episode in the Pearl River Delta of China, Atmos. Environ. 38, 6737-6750, 2004.

Ding, A., Wang, T., Xue, L. K., et al.: Transport of north China air pollution by midlatitude cyclones: Case study of aircraft measurements in summer 2007, J. Geophys. Res., 114, D08304, doi:10.1029/2008JD011023, 2009.

Draxler, R. R. and Rolph, G. D.: HYSPLIT (HYbrid Single-Particle Lagrangian Integrated Trajectory) Model access via NOAA ARL READY Website (http://www.arl.noaa.gov/ready/hysplit4.html). NOAA Air Resources Laboratory, Silver Spring, Maryland, USA, 2003.

Environmental Protection Department (EPD): Air Quality in Hong Kong 1999. Air Science Group, Environmental Protection Department, the Government of the Hong Kong Special Administrative Region, 2000.

Environmental Protection Department (EPD): Air Quality in Hong Kong 2006. Air Science Group, Environmental Protection Department, the Government of the Hong Kong Special Administrative Region, 2007.

Feng, Y. L., Wen, S., Chen, Y. J., Wang, X. M., Lu, H. X., Bi, X. H., Sheng, G. Y., and Fu, J. M.: Ambient levels of carbonyl compounds and their sources in Guangzhou, China, Atmos. Environ., 39, 1789-1800, 2005.

Godish, T.: Air Quality, 4th edition, Lewis Publishers, Boca Raton, USA, 2004.

Guo, H., Lee, S. C., Louie, P. K. K., and Ho, K. F.: Characterization of hydrocarbons, halocarbons and carbonyls in the atmosphere of Hong Kong, Chemosphere, 57, 1363-1372, 2004.

Guo, H., Wang, T., Blake, D. R., Simpson, I. J. Kwok, Y. H., and Li, Y. S.: Regional and local contributions to ambient non-methane volatile organic compounds at a polluted rural/coastal site in Pearl River Delta, China, Atmos. Environ., 40, 2345-2359, 2006.

Guo, H., So, K. L., Simpson, I. J., Barletta, B., Meinardi, S., and Blake, D. R.: C1-C8 volatile organic compounds in the atmosphere of Hong Kong: Overview of atmospheric processing and source apportionment, Atmos. Environ., 41, 1456-1472, 2008.

Guo, H., Ding, A.J., Wang, T., et al.: Source origins, modeled profiles, and apportionments of halogenated hydrocarbons in the greater Pearl River Delta region, southern China, J. Geophys. Res., 114, D11302, doi:10.1029/2008JD011448, 2009.

Ho, K. F., Lee, S. C., and Tsai, W. Y.: Carbonyl compounds in the roadside environment of Hong Kong, J. Hazard. Mater., 133, 24-29, 2006.

Huang, J. P., Fung, C. H., and Lau, K. H.: Integrated processes analysis and systematic meteorological classification of ozone episodes in Hong Kong, J. Geophys. Res.-Atmos., 111, D20309, doi:10.1029/2005JD007012, 2006.

Jiang, F., Wang, T. J., Wang, T. T., Xie, M., and Zhao H.: Numerical modeling of a continuous photochemical pollution episode in Hong Kong using WRF chem., Atmos. Environ., 42, 8717-8727, 2008.

Kok, G. L., Lind, J. A., and Fang, M.: An airborne study of air quality around the Hong Kong territory, J. Geophys. Res.-Atmos.,
102, 19043-19057, 1997.

Lam, K. S., Wang, T., Chan, L. Y., and Liu, H. Y.: Observation of surface ozone and carbon monoxide at a coastal site in Hong Kong, in: Proceedings of Quadrennial Ozone Symposium, 1998.

Lam, K. S., Wang, T. J., Wu, C. L., and Li, Y. S.: Study on an Ozone Episode in Hot Season in Hong Kong and Transboundary Air Pollution over Pearl River Delta Region of China, Atmos. Environ. 39, 1967-1977, 2005.

Lee, S. C., Chiu, M. Y., Ho, K. F., Zou, S. C., and Wang, X. M.: Volatile organic compounds in urban atmosphere of Hong Kong, Chemosphere, 48, 375-382, 2002.

Lee, Y. C., Calori, G., Hills, P., and Carmichael, G. R.: Ozone episodes in urban Hong Kong 1994-1999, Atmos. Environ., 36, 1957-1968, 2002.

Lee, Y. C. and Savtchenko, A.: Relationship between Air Pollution in Hong Kong and in the Pearl River Delta Region of South China in 2003 and 2004: An Analysis, J. Appl. Meteorol. Climatology, 45, 269-282, 2006.

Liu, Y., Shao, M., Lu, S., Chang, C. C., Wang, J. L., and Chen, G.: Volatile Organic Compound (VOC) measurements in the Pearl River Delta (PRD) region, China, Atmos. Chem. Phys., 8, 15311545, 2008, http://www.atmos-chem-phys.net/8/1531/2008/.

NRC (US National Research Council): Animals as Sentinels of Environmental Health Hazards. National Academy Press, Washington DC, USA, 1991.

Skamarock, W. C., Klemp, J. B., Dudhia, J., Gill, D. O., Barker, D. M., Wang W., and Powers, J. G.: A description of the Advanced Research WRF Version 3. NCAR Tech Notes-475+STR (http: //www.mmm.ucar.edu/wrf/users/docs/arw_v3.pdf), 2008.

Seinfeld, J. H. and Pandis, S. N.: Atmospheric Chemistry and Physics: from air pollution to climate change, $2^{\text {nd }}$ edition. Wiley Publisher, New Jersey, USA, 2006.

Sin, D. W. M., Wong, Y. C., and Louie, P. K. K.: Monitoring of ambient volatile organic compounds at two urban sites in Hong Kong from 1997 to 1998, Indoor Built Environ., 9, 216-227, 2000.

So, K. L. and Wang, T.: On the local and regional influence on ground-level ozone concentrations in Hong Kong, Environ. Pollut., 123(2), 307-317, 2003.

So, K. L. and Wang, T.: C3-C12 non-methane hydrocarbons in subtropical Hong Kong: spatial-temporal variations, sourcereceptor relationships and photochemical reactivity, Sci. Total Environ., 328(1-3), 161-174, 2004.

Stohl, A.: Computation, accuracy and applications of trajectories - A review and bibliography, Atmos. Environ., 32, 6, 947-966, 1998.

Stohl, A., Forster, C., Frank, A., et al.: Technical note: The Lagrangian particle dispersion model FLEXPART version 6.2, Atmos. Chem. Phys., 5, 2461-2474, 2005, http://www.atmos-chem-phys.net/5/2461/2005/.

Stohl, A., Forster, C., Eckhardt, S., et al.: A backward modeling study of intercontinental pollution transport using aircraft measurements, J. Geophys. Res., 108(D12), 4370, doi:10.1029/2002JD002862, 2003.

Tang, J. H., Chan, L. Y., Chan, C. Y., Li, Y. S., Chang, C. C., Liu, S. C., $\mathrm{Wu}, \mathrm{D}$. , and Li, Y. D.: Characteristics and diurnal variations of NMHCs at urban, suburban, and rural sites in the Pearl River Delta and a remote site in South China, Atmos. Environ., 41, 8620-8632, 2007. 
Wang, X. M., Carmichael, G., Chen, D. L., Tang, Y. H., and Wang, T. J.: Impacts of different emission sources on air quality during March 2001 in the Pearl River Delta (PRD) region, Atmos. Environ., 39, 5227-5241, 2005.

Wang, T., Lam, K. S., Lee, A. S. Y., Pang, S. W., and Tsui, W. S.: Meteorological and chemical characteristics of the photochemical ozone episodes observed at Cape D'Aguilar in Hong Kong, J. Appl. Meteorol., 37, 1167-1177, 1998.

Wang, T., Wu, Y. Y., Cheung, T. F., and Lam, K. S.: A study of surface ozone and the relation to complex wind flow in Hong Kong, Atmos. Environ., 35, 3203-3215, 2001.

Wang, T. and Kwok, J. Y. H.: Measurement and analysis of a multiday photochemical smog episode in the Pearl River Delta of China, J. Appl. Meteorol., 42, 404-416, 2003.

Wang, T., Poon, C. N., Kwok, Y. H., and Li, Y. S.: Characterizing the temporal variability and emission patterns of pollution plumes in the Pearl River Delta of China, Atmos. Environ., 37, 3539-3550, 2003.

Wang, T., Guo, H., Blake, D. R., Kwok, Y. H., Simpson, I. J., and Li, Y. S.: Measurements of Trace Gases in the Inflow of South China Sea Background Air and Outflow of Regional Pollution at Tai O, Southern China, J. Atmos. Chem., 52, 295-317, 2005.

Wang, T. J., Lam, K. S., Xie, M., Wang, X. M., Carmichael, G., and Li, Y. S.: Integrated studies of a photochemical smog episode in Hong Kong and regional transport in the Pearl River Delta of China, Tellus 58B, 31-40, 2006.

Ward, J. H.: Hierarchical grouping to optimize an objective function, J. Am. statistical assoc., 48, 236-244, 1963.
Warneck, P.: Chemistry of the Natural Atmosphere, 2nd Edition, Academic Press, San Diego, USA, 2000.

Zhang, J., Wang, T., Chameides, W. L., Cardelino, C., Kwok, J., Blake, D. R., Ding A. J., and So, K. L.: Ozone production and hydrocarbon reactivity in Hong Kong, Southern China, Atmos. Chem. Phys., 7, 557-573, 2007, http://www.atmos-chem-phys.net/7/557/2007/.

Zhang, J. M., Wang, T., Ding, A. J., Zhou, X. H., Xue, L. K., Poon, C. N., Wu, W. S., Gao, J., Zuo, H. C., Chen, J. M., Zhang, X. C., and Fan, S. J.: Continuous measurement of peroxyacetyl nitrate (PAN) in suburban and remote areas of western China, Atmos. Environ., 43, 228-237, 2009.

Zhang, Y. H., Shao, K. S., Tang, X. Y., and Li, J. L.: The study of urban photochemical smog pollution in China, Acta Scientiarum Naturalium Universitatis Pekinensis, 34, 393-399, 1998.

Zhang, Y. H., Xie, S. D., Zeng, L. M., and Wang, H. X.: The traffic emission and its impact on air quality in Guangzhou area, J. Environ. Sci., 11(3), 355-360, 1999.

Zhang, Y. H., Su, H., Zhong, L. J., Cheng, Y. F., Zeng, L. M., Wang, X. S., Xiang, Y. R., Wang, J. L., Gao, D. F., Shao, M., Fan, S. J., and Liu, S. C.: Regional ozone pollution and observation-based approach for analyzing ozone-precursor relationship during the PRIDE-PRD2004 campaign, Atmos. Environ., 42, 6203-6218, 2008.

Zhou, X. L., Civerolo, K., and Dai, H. P.: Summertime nitrous acid chemistry in the atmospheric boundary layer at a rural site in New York State, J. Geophys. Res.-Atmos., 107(D21), doi:10.1029/2001JD001539, 2002. 